Portland State University

PDXScholar

1976

\title{
A historical analysis of the traditional Japanese decision-making process in contrast with the U.S. system and implications for intercultural deliberations
}

Shoji Mitarai

Portland State University

Follow this and additional works at: https://pdxscholar.library.pdx.edu/open_access_etds

Part of the Speech and Rhetorical Studies Commons

Let us know how access to this document benefits you.

\section{Recommended Citation}

Mitarai, Shoji, "A historical analysis of the traditional Japanese decision-making process in contrast with the U.S. system and implications for intercultural deliberations" (1976). Dissertations and Theses. Paper 2361.

https://doi.org/10.15760/etd.2358

This Thesis is brought to you for free and open access. It has been accepted for inclusion in Dissertations and Theses by an authorized administrator of PDXScholar. Please contact us if we can make this document more accessible: pdxscholar@pdx.edu. 
AN ABSTRACT OF THE THESIS OF Shoji Mitarai for the Master of Arts in Speech Communication presented February 16, 1976.

Title: A Historical Analysis of the Traditional Japanese Decision-Making Process in Contrast with the U.S. System and Implications for Intercultural Deliberations.

APPROVED BY MEMBERS OF THE THESIS COMMITTEES:

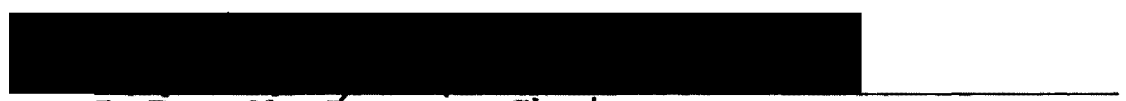

LaRay M. Barna, Chairman
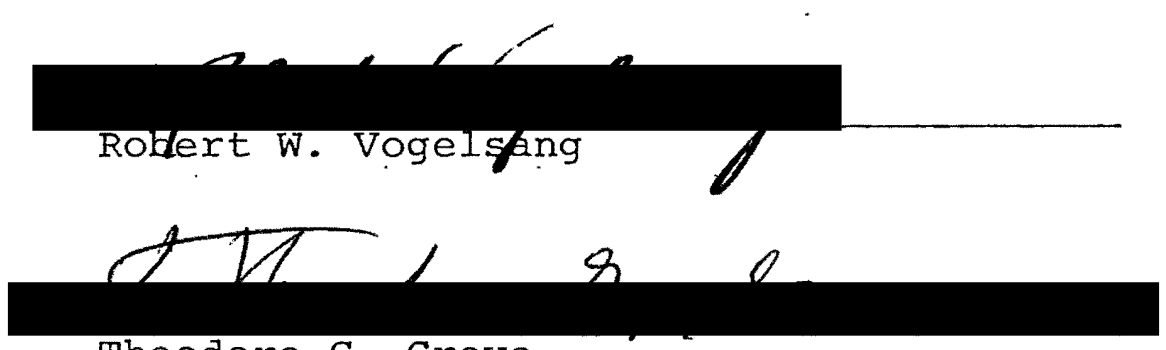

Theodore G. Grove

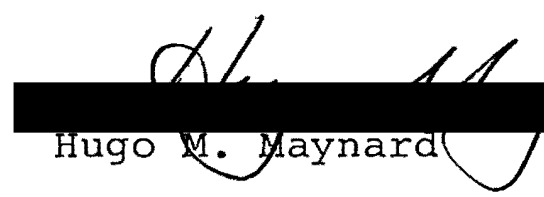

The purpose of this research is to (1) describe and analyze the different methods used by Japanese and by U.S. persons to reach agreement in small group deliberations, (2) discover the depth of commitment and personal involvement with these methods by tracing their historical beginnings, and (3) draw implications 
from (1) and (2) as to probability of success of current problem solving deliberations involving members of both groups.

In the Yayoi period of Japanese history (250 B.C. 300 A.D.), a special set. of circumstances in both the ecological and cultural sphere encouraged the consensus type of decision-making and commensurate cultural norms to develop among the inhabitants of the Japanese archipelago.

Following the Yayoi by some 300 years was the Nara period of Prince Shotoku who attempted to reform and modernize Japan by bringing in many cultural attainments such as the Chinese writing system, some of the grammatical features of Korean Language, and religious philosophies of India.

Western influence after World War II did not greatly modify the deeply embedded patterns of thought, ethos, behavior, communication and decision-making basis.

Two selected elements of the Japanese culture are analyzed: (1) a system of hierarchy which encompasses the sense of discipline, benevolence, self-depreciation, nonverbal behavior (use of the bow) and verbal behavior and (2) need for harmony which includes vagueness of language, advatism or use of intuition (awareness of other's needs and feeling via nonverbal cues) and the humane sensibility.

These two elements still permeate todays' Japanese society and affect communication styles. There is a descrip- 
tion' of both the traditional consensus method of reaching agreement which emphasizes non-verbal aspects and the modern day method which encourages the verbal communication. In either case, the guiding spirit of decision-making is harmony and the goal is almost entirely directed toward cooperation. The cultural elements deeply entrenched in Japanese history provide this system of decision making.

The American dialectic method of reaching agreement, on the contrary, places a high value on personal contributions, convictions, arguments and achievements. Conflict is a direct result of the American method and is considered to be desirable as well as necessary in order to reach a good conclusion. By the same token, disagreement occurs more frequently. This means that in an intercultural setting a great deal of miscomunication may be occurring. Under what conditions will critical incidents be likely to occur when the two negotiating groups encounter is hypothesized. The American method is contrasted with Japanese method and it was found that they are strikingly different and achieve different specific goals. 


\begin{abstract}
A HISTORICAL ANALYSIS OF THE TRADITIONAL JAPANESE DECISION-MAKING PROCESS IN CONTRAST WITH THE U.S. SYSTEM AND IMPLICATIONS FOR INTERCULTURAL DELIBERATIONS
\end{abstract}

By

SHOJI MITARAI

A Thesis submitted in partial fulfillment of the requirements for the degree of MASTER OF ARTS in SPEECH COMMUNICATION

Portland State University 1976

(C) Shoji Mitarai 1976 
TO THE OFFICE OF GRADUATE STUDIES AND RESEARCH:

The members of the Committee approve the thesis of Shoji Mitarai presented February 16, 1976.
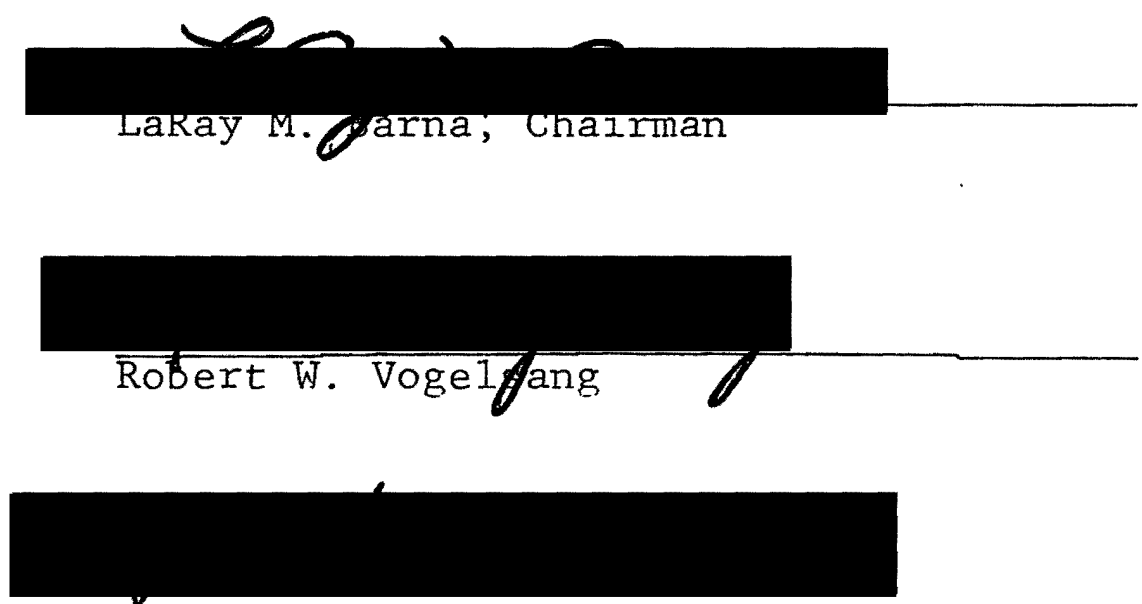

Theodore G. Grove

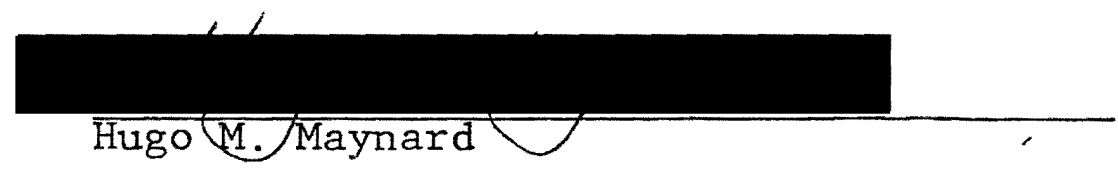

APPROVED :

Robert W. Vogelsang, Chairmgh, Department of Speech Communication Richard B. Hallets Acting Deq of Graduate Studies and Research 


\section{ACKNOWLEDGEMENT}

The writer's deepest acknowledgement is first to his committee members Professor LaRay M. Barna, Dr. Robert W. Vogelsang, Dr. Theodore G. Grove, and Dr. Hugo M. Maynard. In acknowledging the help the writer received on this thesis, his heartfelt appreciation is first of all extended to the committee members who have assisted him in preparing this thesis. This is especially true in regard to Professor Barna who spent much of her time and energy assisting the writer with encouragement and invaluable suggestions as to intercultural orientations and semantics throughout his academic year and during her sabbatical period from University of Minnesota where she devoted herself to the investigation of her research on intercultural communication and area studies as a visiting scholar during summer months.

The writer wishes to take this opportunity to thank Professor R. Carol Healy, the head of Foreign Language Department and $\mathrm{Mr}$. Sho Dozono; the head of Japanese Language for their assistance in securing the position the writer has held as a graduate teaching assistant in Japanese. The writer's work under the guidance of Mr. Dozono has opened new vistas of understanding in teaching method in terms of language and culture and also has given him fresh prespectives on intercultural communication. 
The writer should also like to show his profound gratitude to Dr. Fujio Harada, a visiting researcher from Chuo University, who extended generous assistance and cooperation. The writer also received generous suggestions and contributions not only from Mr. Kirk Downing, now in Los Angeles, and Mr. Gregory Chan at the University of Washington but from many of the writer's friends both on this shore and in Japan as well as both sides of the ocean. In addition, there were various individuals who contributed to the development and completion of this thesis. The writer feels indebted to $\mathrm{Mr}$. Kyoji Tanaka, an economic specialist at the American Consulate in Sapporo, who first brought the writer an awareness of cross-cultural understanding and rapport among nations through English instructions years ago.

And finally, the writer should like to take the liberty of adding that much support and help was given by his wife, Michiyo, and by his mother, Sadako Mitarai, across the Pacific. 
TABLE OF CONTENTS

PAGE

ACKNOWLEDGEMENT • • • • • • • • • • • • • • •

CHAPTER

I INTRODUCTION . . . . . . . . . . . 1

Justification of the Study . . . 5

Review of Literature ... . . . . 9

Statement of Purpose . . . . . 10

Thesis Statement . . . . . . 10

Research Method . . . . . . 11

Chapter Notes . . . . . . . . 13

II HISTORICAI BASIS OF JAPANESE COMMUNICATION FORMS •. . . . . . . . . . 15

Jomon Period and Before . . . . 15

Yayoi Period . . . . . . . . 16

Yamato Period . . . . . . . . . 19

Nara Period . . . . . . . . . 20

Feudalistic Period . . . . . . 24

Tokugawa Period . . . . . . . 25

Meiji Period . . . . . . . . 28

Taisho Period . . . . . . . 30

Showa Period . . . . . . . . 30 
Summary of Historical Elements Influencing the Japanese Communication system with regard to Consensus . . . . . . . . . . .

Chapter Notes . . . . . . . .

III TRADITIONAL JAPANESE CULTURAL EIEMENTS AND SELECTED COMMUNICATION FORMS THAT HAVE BEEN RETAINED • • • • • . • • •

A. THE SYSTEM OF HIERARCHY . •

Sense of Discipline . . . . 42

Benevolence . . . . . . . 46

Self-Depreciation . . . . . 47

Non-Verbal Behavior (Use of Bow) 47

Verbal Behavior . . . . . . 48

B. NEED FOR HARMONY • • . • . 53

Vagueness of Language . . . 54

Advatism or Use of Intuition 56

The Humane Sensibility . . . 61

C. AGREEMENT BY CONSENSUS . . . 63

Chapter Notes . . . . . . 70

IV U.S. DIALECTIC METHOD OF REACHING

AN AGREEMENT • • • • • • • • • • •

Definition of Dialectics . . . 74

Development of the Dialectic

Approach in U.S. ......... •

Contrast of U.S. and Japanese Method of Reaching Agreement . . 
vii

V SUMMARY AND IMPLICATIONS . . . . . . 86

Chapter Notes . . . . . . . 94

APPENDIX I . . : . . . . . . . . . . . 95

APPENDIX II . . . . . . . . . . . . 104

APPENDIX III . . . . . . . . . . . . . . 109

APPENDIX IV . . . . . . . . . . . . . 116

APPENDIX V • . . . . . . . . . . . . . 117

APPENDIX VI . . . . . . . . . . . . . 118

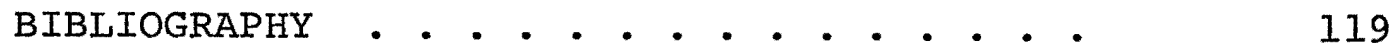




\section{CHAPTER I}

\section{INTRODUCTION}

It has often been said that we are living in an age of instability and flux where we are experiencing problems due to exhaustion of world-wide natural resources, overpopulation, environmental degradation and other pressing matters. This has created an age of anxiety and danger, and at the same time one of great challenge. Societies of the world are cutting away from old moorings and entering into new historic dimensions.

When the writer looks at the world of international affairs, particularly at U.S. - Japan relations, he can see clearly this drift into new areas." There is also evidence of new strains and a slow deterioration of friendly relations. One cause could be the competition for global resources, but it is doubtless owed to a combination of complex factors -including the problem of communication in this new era of forced interaction.

Due to advances in electronics, transportation systems and communications technology, the importance of physical distance is diminishing. Nevertheless, this does not necessarily make it possible to decrease psychological proximity and the sharing of meanings upon which communication depends. 
Many people believe that bringing more representatives of nations together more frequently, by whatever means, will inevitably result in a greater understanding of each other's personalities and problems and hence' a greater chance for all to live together in prosperity. But where is the proof?

Authorities in the field of speech communication are reporting the opposite viewpoints. Dean Barnlund states that frequent interaction does not improve intercultural relations. He believes that merely being together without any understanding of the process of communication can lead to the saying, "familiarity breeds contempt", as well as misunderstanding. 1

LaRay Barna also states, "Professionals in the field of speech communication are likely to take a different view. Being fully aware of the complexities of interpersonal interaction, even within cultural groups, they know better than to equate contact with communication." 2

U.S. - Japan relations have been in existence for more than 180 years and have included massive interchanges in the fields of cultural arts, politics, business, economics and others, including intense interaction after World War II. There is still a lack of "reaI" communication between the two countries. This is substantiated by Edwin 0. Reishauer, a former American Ambassador to Tokyo and currently a professor at Harvard, when he said, "Our communication is extremely poor. Communication between the two societies is always a problem ..."3 
As communications between the two nations increases, misunderstandings lead to friction and conflict will likely multiply. A primary cause of these misunderstandings could be the basic unbridgeable differences in the styles of communication and assumptions about communication between Japanese and Americans. This can be clarified by mentioning several cases of misunderstanding that have taken place in recent years in government and business between the two countries. Primary among these are the so-called Nixon Shocks regarding U.S. rapproachment with mainland China without prior consultation with Japan; the Textile Issue, the Soybean Issue, and other discussions in Tokyo concerning Iumber. In all of the above examples, sides were taken in that the Japanese felt that they were reaching agreement on one point, whereas the U.S. felt that the Japanese were transmitting something completely different. Evidence of this is cited by Richard Halloran:

The after math of the conference between American and Japanese officials a week ago has pointed up two fundamental reasons for the sorry state of relations between Washington and Tokyo. The first is that there is a communications gap nearly as wide as the Pacific Ocean. Each side is listening to each other but is not hearing what is said. Consequently, misunderstandings pile on misunderstandings. ${ }^{4}$

Below is another example concerning President Nixon's remarks about the textile negotiations. This was, in fact, unsuccessful in terms of communication despite the note of success found in the Weekly Presidential Document. The article 
reads as follows:

We have just concluded a series of meetings in which the Prime Minister and I have had a farranging and very comprehensive discussion of a number of issues. I think it can be safely said that this is the most comprehensive discussion which has ever taken place between the Prime Minister of Japan and the President of the United States. It has also been a very constructive discussion ........... We have found that on many major issues we have substantial agreement......

In response to this, Prime Minister Sato stated:

(During the two-day summit talks with the President in San Clemente), I am confident these meetings have contributed to strengthen the unshakeable relationships of mutual trust and interpendence, ${ }_{5}$ tween the peoples of the United States and Japan. 5

In spite of these feelings of confidence, in the final analysis the results were that, due to a lack of understanding, both sides came to a loggerhead and criticized each other. "The public has often heard of the increasing strain in U.S. - Japanese relations, particularly since the discord on the textile negotiations between the two countries." 6 From the experience of the writer who has lived in the United States and has some knowledge of the American system and even more knowledge about the Japanese system, he cannot emphasize enough that major overall communication problems are apparent. 


\section{JUSTIFICATION OF THE STUDY}

U.S. - Japan relations have been in existence more than 180 years since the American vessel "Lady Washington landed in Kushimoto, Japan in 1791, some 60 years before Commodore Matthew Perry opened the Orient". 7 Hopkins recites an episode of the voyage:

They went into a harbour on the southern coast of Japan where they were received by the natives with the greatest hospitality. Here Captain Kendrick displayed the American flag which is probably the first ever seen in that quarter ... In a few days sail from this they discovered a group of islands to which, on account of the natives bringing water off to sell, was given the name of Water Islands because of their not being down on any chart existent. The natives of these islands as well as those of Japan and the Chinaman could not understand each other in talking, but in writing they could well. Their tarry among these islands was short. The two vessels parted company soon after leaving them, each making the best of his way to this coast.

The relations between the two countries since that time have been characterized as amicable and friendly with the exception of the Pacific War. Edwin 0. Reishaur, in his book, "The Meaning of the Japanese - American Partership" put it this way:

The relationship between Japan and the United States (over the 120 years) could be accurately described not just as association but as friendship. (In) the talks between Prime Minister Ikeda and President Kennedy last June in Washington, I noticed the term "partnership" was used more agd more, and it has been heard a great deal ever since. 
At present, at least on the surface, there seems to be no serious conflict in basic interests between the two countries. Professor Kitamura stated these interests to be: (1) the maintenance of peace and prosperity in Asia and the world; (2) the preservation of a political ideal which will allow independent nations - states, no matter how competitive to live in a free and peaceful world order; (3) the promotion of free trade on a global basis." 10 on the other hand, emergence of certain conflicts and frictions are apparent in economic, political and business fields. Although Japan's economy has been internationalized to a certain extent and Japan's business community has been exposed to the outside world with the progressive expansion of trade, liberalization as well as capital transaction, Japans's concentration on her economic pursuit in international trade without being involved with international controversy has caused some friction in U.S. - Japanese relations. "Japan's policy is not truly reciprocal because it prevents foreign imports by subtle administrative "guidance" and undue restrictions on foreign capital. Such behavior could be understood as long as Japan was a war-devastated country". 11 Some foreign observers perceive this trend as a trade "war" and express fear that Japan might be on the road to remilitarization. Brzezinski gives a rather gloomy prediction of Japan's future in this respect as opposed to an economist, Herman Kahn, 
who makes rather optimistic views on it. Rolf Clough, who served as a foreign service officer and presently is a senior fellow at the Brookings Institute gives a fair warning: "If Japan again becomes military powerful ... its domestic policies and its attitude toward other countries could not fail to be profoundly altered."12

Although Japan has climbed back to a level of prosperity that made her a so-called Economic Giant, there could be a real danger here. The decade of the 1970's is an age characterized by accelerated changes all over the world, including U.S. - Japanese relations. If the gear shifting of U.S. - Japanese relations cannot keep abreast of the latest changes, both countries might plunge into another period of disaster.

It is high time for both countries to ponder such problems within the framework of International and Intercultural Communications and adjust the communication behavior of the two countries to enable them to make accommodations for the changes affecting the United States and Japan in this multipolar world. Without fine-tuning, so to speak, in communication there is little chance to work together to achieve stability and peace in Asia and throughout the world.

In previous paragraphs, the writer mentioned some of the problems that have developed during U.S. - Japanese relations and briefly touched upon the basic root of these problems: differences in styles of communication. It is 
necessary for the continued improvement of U.S.- Japanese relations to understand how the Japanese styles of communication work and how these communication behaviors themselves may prevent arguments from being reached when in negotiation with U.S. counterparts since they are based on vastly different cultural norms.

During the past several years, a few analysts have presented writings which were composed of the communication behaviors of the Japanese people and U.S. citizens. Most of these have been simple descriptions and have been written for businessmen, tourists and others. They are mainly of the "How to behave while in Japan" or "information on cultural peculiarities on the basis of one's subjective views or observations" type.* These may be helpful to an extent, but if one is to go beyond a superficial and sometimes inaccurate simple recognition of a difference and achieve a deeper understanding of not only how, but why Japanese communication styles differ from American styles, more research is imperative.

Experts investigating this problem should examine the following questions: Are disagreements due to actual or perceptual differences in ideas or attitudes? What misunderstandings and adverse feelings are due to the communication process itself? Since the field of intercultural com-

* A good example is Howard Van Zandt's book "How to Negotiate in Japan". See the footnote 16 in the Chapter Notes. 
munication is so broad that the questions such as the those above need to be asked and explored by other researchers and applied to many instances in the future. This investigation will be limited to the two national groups previously described and in the area of interpersonal and small group decision-making.

\section{REVIEW OF LITERATURE}

"Social Psychology Group Process For Decision-Making", 13 "The Dynamics of Discussion", 14 "Organizational DecisionMaking"15 and others already include descriptions of U.S. systems of reaching agreement. Less well known but also available are descriptions of the Japanese system such as "How to Negotiate in Japan", 16. "Traditional Japanese Management Decision-Making", 17. "Background, Characteristics and Recent Trend in Japanese Management", 18 and others. Very few authors have explored intercultural communication. There is a need for this to be brought to the awareness of those involved not only in the field of communication and area studies, but in publications and teaching. Future study should be based on this.

What is needed is better comprehension of why each behaves separate ways; a discovery of the cultural and traditional roots. This will lead to a better recognition and appreciation of the systems by the culturally exposed participants, thus allowing them to accept and understand re- 
spectfully the subtle distinctions within those systems.

Better communication between people anywhere is desirable, but the contemporary political scene makes the need for improved problem solving techniques between negotiators vitally important. This study will not deal with communication forms of journalistic writing or formal written exchanges. It will not approach the area of mass media or broadcasting. It is intended to explore the form of communication taking place most often in the business and government community, people talking with people, or interpersonal communication.

\section{STATEMENT OF PURPOSE}

The purpose of this study is to (1) describe and analyze the different methods used by Japanese and U.S. persons to reach agreement in small group deliberations, (2) discover the depth of commitment and personal involvement with these methods by tracing their historical beginnings, and (3) draw implications from (1) and (2) as to the probability of success of current problem solving deliberations involving members of both groups.

\section{THESIS STATEMENT}

This thesis will be based upon the following assumptions: (1) Much of our difficulty in communication across cultures comes from the fact that there is a lack of understanding and knowledge about one's own culture's communica- 
tion patterns and how they differ from anothers. (2) Today's world problems and increased interaction make this study of intercultural communication highly important.

There are three statements that are made in this thesis. (1) There is a difference in communication styles between the United States and Japan within negotiating groups of these two nations, specifically differences in small group deliberation and methods of reaching agreement.

These differences are due to cultural heritages and historical developments and are therefore deeply rooted in each society. (3) The differences often stand in the way of effective intercultural deliberations and cause problems:

\section{RESEARCH METHOD}

The research plan of this thesis is as follows:

Search historical records for the basis of today's Japanese traditional lifestyles and discover the emerging cultural influences which have shaped and molded Japanese thoughts, behaviors and communication patterns.

(2) Record these cultural influences in a time sequence to, provide a sense and feeling for the depth that these communication behaviors which are retained and rooted in the culture.

(3) Describe the movement of the old patterns into present day communication forms to see whether the influences have changed or erased traditional elements (4) Repeat (1), (2) and (3) in a more limited fashion with regard to U.S. decision making 
process. (5) Draw the contrast of U.S. and Japan methods of reaching agreement. (6) Illustrate examples of the typical interaction when representatives from both countries encounter in the small group deliberation setting.

The writer made a synthesis of carefully selected descriptions, analysis and views of both Japanese and American writers and researchers. He also included the results of his direct observations, day to day experiences, interviews and field work in Japan and the United States.

This leads to new insights and self-awareness of our historically and culturally influenced communication styles and at the same time is a basis for future researchers. 
CHAPTER I. NOTES

${ }^{1}$ Dean C. Barnlund, Public and Private Self in Japan and the United States, (Tokyo: Simul Press, 1975), p. 139.

${ }^{2}$ LaRay M. Barna, Stumbling Blocks in Interpersonal Intercultural Communication in Intercultural Communication: A Reader, (Belmont, California: Wadsworth Pub. Company, Inc., 1972), p. 241.

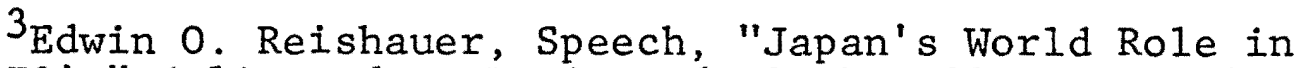
the 1970's" delivered at Lewis and Clark College, Portland, Oregon, May 9, 1973.

${ }^{4}$ New York Times, August 3, 1972.

${ }^{5}$ Weekly Compilation of Presidential Documents, Monday, Jan. 10, 1972, Vo1. 8, No. 2 p. 34.

${ }^{6}$ Gerald L. Curtis, Columbia Journal, World Business Vo1. VI. No. 1, Jan.-Feb. 1971, p. 72.

7 The Oregonian, April 19, 1975.

${ }^{8}$ Frederic G. Young, Oregon Historical Quarterly, Vol. 23, 1922, p. 286.

${ }^{9}$ Edwin 0. Reishauer, A New Look at Modern History (Tokyo: Genbasho, 1964), p. 67.

${ }^{10}$ Hiroshi Kitamura, Psychological Dimensions of U.S.Japanese Relations, (Cambridge, Mass., Harvard Univ., 1971), p. 3 .

$11_{\text {Ibid. p. } 5 .}$

12 The Oregonian, Japan Must be Focus of Asian Reassessment, May, 1975.

13 Barry E. Collins \& Harold Guetzkow, A Social Psychology of Group Process for Decision-Making (N.Y. John Wiley \& Sons, INO, 1964).

${ }^{14}$ Dean C. Barnlund \& Franklyn S. Haiman, The Dynamics of Discussion (Boston: Houghton Mifflin Company, 1960). 
15

Fremont A. Shall, Jr. \& Andre L. Delberg \& L. L. Cunings, Organizational Decision-Making (New York, McGraw Hil1 Book Company, 1970).

16Howard E. Van Zandt, "How to Negotiate in Japan" in Harvard Business Review, (November-December, 1970), pp. 45-46.

$17 \mathrm{~K}$. Koda \& H. H. Grazer, "Traditional Japanese Management Decision-Making" Management International Review, Vo1. 8 2-3 (1969), pp. 124-131.

18 Susumu Takamiya, Background, Characteristics and Recent Trends in Japanese Management (London: The British Institute of Management, 1970). 
CHAPTER II

HISTORICAL BASIS OF JAPANESE COMMUNICATION FORMS

To find the root of Japanese communication, a look deep into Japan's past and an understanding of the type of land the inhabitants live in is essential.

\section{JOMON PERIOD (250 B.C. and Before)}

The Japanese archipelago had its origin in submarine volcanic activity on the floor of the Pacific Ocean. As the volcanoes increased in size and height and the base spread, the Japanese archipelago gradually began to appear through the surface of the Pacific. ${ }^{1}$ Over eons of time, the island's present mass of approximately 140,000 square miles came into being, so mountainous that only 15 percent of its surface area could support human habitation. This scarcity of arable land was to affect deeply the people who were to settle this land chain in that it enforces closeness and cooperative living.

Scientists speculate those early settlers began to drift in across land bridges to the mainland and were composed of Peking, Java Man and other homines. Collectively, they formed the Jomon culture. ${ }^{2}$ It was not until milleniums later that culture as we know it began to make its appear- 
ance in Japan. By this time, about 7,000 B.C. the land bridges were no longer in existence and Japan had been completely isolated from outside human influence for tens of thousands of years. Our knowledge of those Jomon people comes largely from the pottery which they left behind and also from their grave mounds.

$$
\text { II. YAYOI PERIOD (250 B.C. - } 300 \text { A.D.) }
$$

The primitive hunters and gatherers of the Jomon culture gave way in the beginning of the Christian era to a new group of people called the Yayoi who entered Japan in about 250 B.C. from continental Asia. It was the Yoyoi people who initiated the creation of Japanese culture as we now know it today. These early settlers brought with them wet rice cultivation and a strong tie with their fellows on the Asian mainland, particularly Korea. By 100 A.D., the Yayoi culture was out in front to dominate the central area of Japan.

As this wet rice cultivation spread and new immigrants arrived from Asia, the Yayoi culture exercised its dominance throughout Japan, pushing the Jomon peoples into the farthermost inhospitable regions of the archipelago.

By 300 A.D., the Yayoi people had established semiunified states controlling virtually all of Japan. A basic understanding of this early culture group is vital as well as crucial in understanding the later development of com- 
munication and culture in Japan from two standpoints.

The first standpoint is the identification of a native Japanese culture by the cultivation of rice and cultural norms that must go with it. ${ }^{3}$ The second is the connection with the more advanced mainland cultures of Korea and China and their continual interaction with those people throughout the next several centuries. Wet rice cultivation, the gift of the Yayoi people to Japan, requires sedentary communities with a large measure of cooperation between the individuals in the community. Conflict in this sort of community can be extremely detrimental both to the existence of the community and to the individuals in the community.

In such a society, an individual who asserts himself will hurt the feelings of others and thereby do harm to himself by interfering with the normal cooperative relationships existing between groups. The significant criteria for judging actions as well as behavior was whether they were right or best for the group. 'By the same token; the concept of territoriality leading to the concept of family and we-group identification began to emerge. The Japanese learned to adjust themselves to this type of familial society and created forms of expression suitable to life in it. Thus began the principle of heteronomy which is held in conjunction with the Amae psychology as core personality characteristics of today's Japanese people. 5 The religion of the Yayoi communities consisted of worship of tutelary 
gods and local deities. Even today, there is a tendency among Japanese people to worship and settle close around their local deities and gods. 6 This perpetuation of the community is deeply rooted in the people and has led to their stressing of interpersonal relationships and the spirit of harmony and concord in particular. The Japanese have learned to place a special importance to the human nexus and group solidarity in that manner with relative disregard to the individual. All of these cultural phenomena spring from the nature of wet rice cultivation and are evident throughout the wet rice cultivation zones of Eastern Asia. These norms are, for the most part, ecologically essential for the survival of the group.

The second major reason that the Yayoi is important in today's context is that they provided a close contact, with the people of the Korean Peninsula and through them with the people of $\mathrm{China}^{7}$ leading to close identity with these people. As a matter of fact, the bond between southern Kyushu, the southernmost island of Japan, and the people of southern Korea was probably closer than the bond existing between the people of Kyusu and the people of Honshu to the north of them. Through this largely friendly association came the advanced ideas of the great Chinese state which enabled early Yayoi people to advance their political system far more quickly than otherwise might have happened. This cultural input from Sinitic civilization to the West enabled early Yayoi 
people to develop at a noticeably faster degree than any other comparable wet rice cultivation society. ${ }^{8}$ Most of the cultural elements in the Japanese society which are regarded as native elements rather than imported elements, and which will be stressed several times in this study are derived from the Yayoi culture.

\section{YAMATO PERIOD (CA. 300 A.D. - 710 A.D.)}

Following the Yayoi period was the Yamato period during which the Japanese people began to develop small kingdoms throughout Kyushu and southern Honshu. These early kingdoms began direct association with the Chinese dynasties. The earliest known exchange of envoys occurred in 57 A.D., when the Japanese kingdoms of $\mathrm{Nu}$ sent envoys to the Han dynasty. ${ }^{9}$ Again in $130 \mathrm{~A} . \mathrm{D}$., it is known that the ruler of Yamatai, Himiko, sent envoys to the Chinese kingdoms of Wei. These early kingdoms gave way, in 350 A.D., to the establishment of Yamato, which exercised hegemony over all of Japan through a single imperial family. This ushered in the Yamato period which was to last about 200 years and was characterized by the further refinement: of the developing Japanese system, as well as the development of the aforementioned leader, Himiko's matriarachial society. ${ }^{10}$ For Himiko, unlike later rulers, was a woman. This period was also characterized by isolation from China and as the Japanese grew in power, armed conflict with the people of 
the Korean Peninsula ensued. The Yamato period was the period of the first centralized states in Japan.11. It was also a period of primitive deities and gods, formalized into the Shinto religion. These gods were primarily gods of production, and of natural phenomena. It was also a period of relative isolation with China which lasted until about 600 A.D. with the advent of the power of Prince Shotoku, who brought in the great Nara period.

IV. NARA PERIOD TILL FEUDALISTIC PERIOD (710 A.D. - 1185 A.D.)

During the Nara period, the element of concord between the people was again stressed to an enormous degree in Japan. When Prince Shotoku came to power, relations with China were again regarded as vitally important to Japan. He presided over the introduction of Buddhism and Confucianism from China and helped spread these philosophical ideas among the Japanese people together with Shintoism.

He contended that, "Shinto, Buddhism and Confucianism form the tree that is Japan. Shinto is the root (the character of people and their national traditions, Confucianism the trunk and branches (code of ethics, educational systems and legal institutions), and Buddhism the fruit and flowers (the flower of spiritual life and the fruit of religious sentiment). "12 However, the newly imported Mahayama Buddhism and Confucianism were modified to fit the special circumstances and cultural environment ex- 
isting in Japan. Confucianism came to the fore during the Tokugawa period which shall be discussed later. Prince Shotoku also attached a great importance to production with agricultural rituals in agrarian villages and the ethic and importance of labor were set down. as elements of right behavior. 13 This became firmly rooted behavior and the importance of these ideas continued in Japan. Confucianism, which entered Prince Shotoku's reign, created vertical relationships between individuals in terms of social stratification, with an emphasis on the superior and inferior dichotomy of society. However, Japan, which was a cooperative society in which concord between lord and subject was of principal importance, molded Confucianism into a system which was largely based upon propriety and decorum, not practicality as it was in China. Thus, Confucianism became largely ceremonial in Japan while the native basis of cooperation and compromise was even further enhanced and was given more emphasis.

Prince Shotoku stated, "...people should not merely follow or obey but discussion should be carried on in the atmosphere of concord and harmony. So one might attain right views."14 Confucianism as it was developed and existed in China was virtually the opposite. The great

Confucian scholar Mencius for example, gave a better idea of the general picture: "Great men have their proper business... Some labor with their minds, and some labor with 
their strength. Those who labor with their minds govern others; those who labor with strength are governed by others."15 Therefore, inferiors must listen to and obey superiors. Superiors must look upon the inferiors as their children. Etienne Balazs also explains:

...for the ordinary subject, the cardinal virtue was absolute obedience. Its unalterable aim was to maintain the status quo of the social hierarchy... respecfulness, humility, deference, docility, complete submission and subordination to elders and betters these were the dominant features of the Confucian ethic that helped to cement the hierarchy, creating a patriarchial, paternalistic world in which gradations of rank, from the sovereign downward, were marked."16

More on these seemingly conflicting philosophies is in the summary of this chapter. Thus, Japan developed a social hierarchy based on Confucianism and maintained a cooperative society with native values. With this in mind, it can be stated that the centralized monarchy had little absolute power at any time and did not exist as a dictatorship. Buddhism entered Japan in this era and found far more fertile ground to develop in than Confucianism had, and maintained more of its true character. 17

Buddhism developed with ideas of humanitarianism, moral self-reflection and tolerance along with other spiritual values. The most popular and influential form of Buddhism in Japan was Zen, a mixture of Buddhist with 
Taoism doctrine which originated in China and stressed the value of sudden insight and demeaned the importance of verbal communication. It should be noted here that the writer often comes across such items in print as "Zen Buddhist teaching places great value on silence and the communication of ideas and feelings by non-verbal means."18 Two Zen sects later appeared in Japan, however. One was Rinzai Zen which attached far more significance to non-verbal communication than verbal. The other was Soto Zen which on the contrary placed a stress on the importance of verbal communication. 19 At any rate, the emphasis on non-verbal communication in Japan (linked with concept of Rinzai) and the development of intuitive processes of thinking) found an easy acceptance among people long accustomed to total community solidarity, a uniform moral code and a highly developed community of sympathy and empathy. Along with the introduction of these two great philosophical systems, Chinese culture began to influence the communication of Japan with the introduction of the Chinese system of writing and Chinese literature. The Chinese system was later mixed with the Japanese system to create the unique writing system which exists in Japan today. In addition, "Japan borrowed flowery phraseology on which the Chinese were accustomed to give their reasons for the existence of laws."20 This system also helped the Japanese people to develop the different levels of formality used in the Japanese language and 
the many polite forms which signify interpersonal distance and ranking. 21

V. FEUDALISTIC PERIOD, KAMAKURA AND MUROMACHI (1185 A.D. - 1600 A.D.)

During the Kamakura era (1185-1333) Japanese feuda1istic society took root. Japan, at this time, again became an isolated state. The national life under feudalism was said to be a kind of reaction against foreign stimuli and culture, and also an assertion of native habits and ideas. The feudalistic period in Japan took the form of an absolute dictatorship having wide military powers and existing as an independent dynasty. In these dark ages Japan enhanced the formal dichotomy of superiors and inferiors, and introduced the ethics of the samurai (warrior) code and their absolute control of the society. There was little change during the next several centuries. The Rinzai Zen sect, now became widespread, playing a tremendously significant role in encouraging non-verbal communication. The high value placed on non-verbal communication had a strong impact on the Japanese mind which continues to the present.Some of the Japanese arts, such as Noh drama, the Kabuki theater and the Tea ceremony can be perceived and appreciated only within the framework of non-verbal communication. At the end of the Muromachi period, military dictatorship under the Shogun began to elaborate into the following 
Tokugawa period.

$$
\text { VI. TOKUGAWA PERIOD (1603 A.D. - } 1867 \text { A.D.) }
$$

It was this period that Confucianism which first took root in Japan during the Nara era came to be a potent force ${ }^{22}$ and through the ensuing centuries its effective ideologies penetrated into the situational ethićs, consciousness, customs, valués and thought patterns of the Japanese people. Jack Seward elaborated on Confucianism during this era in the following manner:

The first Tokugawa Shogun recognized the Confucious classics as a source of the political and social stability he was seeking to establish and had them printed in Japan for the first time. Whereas the father-son relationship had been given primary emphasis in China (and had 23 een the strength of the Chinese familial system), 23

Tokugawa preferred that the Japanese give primary obedience to their rulers (to the clan chiefs and through them to the House of Tokugawa). Edwin Reishauer states, "(thére was an emphasis on) the almost ritualistic embodiment of the (obedience) value in specific patterns of conduct... and the external controls they required to form a well-regulated peaceful society." 24 Furthermore, Tokugawa applied his own idea of the way of the warrior. The code of military ethics had a particular emphasis on loyalty, conformity, self-effacement (suppresion of one's own inner feeling and emotions which hinders fulfillment of duty), human feeling and aforementioned obedience to authority. Fulfillment of 
one"s obligations received the utmost emphasis. A rigid and strong hierarchy organized society in terms of class stratification was stressed. 25 Each individual fell in the following classes: (1) warriors, (2) farmers, (3) artisans and, (4) merchants. The warriors (samuri), the most privileged class and obtained such benefits as social stature, education, military discipline, political power and honor. The rest of them were ranked according to their productivity. The farmers were next in line in terms of status, however, merchants were at the bottom. Each knew where he had to fall in his own classification or class and the social hierarchy was clear and thought to be age, occupation, family status, wealth, position in family and marital status. It was through this system that behavior for each position was strictly controlled. Self-effacement thus, has long been thought to be a virtue. One is still socially expected to do this. Expressing one's own emotions and feelings and thought too overtly is considered to be bad taste. Confucian doctrine was the preoccupation of education on the part of youth regardless of their place in the class structure. ${ }^{26}$ Although the "Tokugawa era is characterized as Confucian culture," 27 there was a new movement against this Confucianism. Tokugawa period is also characterized as a period of national seclusion. There appeared scholars like Nakamoto Tominaza, Norinaga Motoori, Shoin Yeshida and others who strongly showed an unfavorable reaction and a marked distaste toward Confucianism and instead advocated national 
1earning, their ideas were strictly laid down to Tokugawa Government. To cite an example, Shoin Yoshida criticized Confucianism and Mencious in this fashion:

It was wrong of Confucius and Mencius to have left their native states and to have served other countries, for a sovereign and a father are essentially the same. To call one's sovereign unwise and dull, and forsake one's native state in order to find another state is like calling one's father foolish and moving from one's house to the next house to become the son of neighbor. The Confucius and Mencius lost sight of this truth and can never be justified. 28

Buddhism, in this period, regarded as being the protection of state, did not develop as it did in preceding centuries. This was because the religion was in reality under the control of the Tokugawa Shogunate who preferred the Confucian warrior image. Due to the above stated influences, so-called Dialectics which had developed in other parts of the world did not penetrate deeply into the Japanese way of thinking, despite scholars Iike Baisen Miura and some others who advocated dualism and the law of the excluded middle. By this time Heizel had set forth the principles of dialectics even more systematically. Neither rhetoric nor oratory could find a place to root in the Japanese mind. 29

It was during the Tokugawa Shogun that mercantilism began to develop and it enabled the Tokugawa regime to flourish. It's impact also eventually caused the downfall of the Tokugawa whose system was not built to handle it. This development of a mercantilism as well as sophisticated urban culture was not the only way in which the foundation for a modernized Japan was being laid during this period. 30 The 
Tokugawa was already in decline when the so-called Black ships of Perry anchored off Uraga in 1853 and sparked the civil war between the Shogun who succeeded in introducing reforms and strengthening her military power and were opponents, young reactionary leaders who swiftly moved to war against Tokugawa regime. It was the Tokugawa who were worn out in the final struggle to be replaced by the Emperor as the most powerful force in Japan.

$$
\text { VII. MEIJI PERIOD (1868̀ A.D. - } 1912 \text { A.D.) }
$$

Meiji period was the second period in Japanese history that the Emperor Mutsuhito held great political power. This momentous change from Tokugawa to Meiji occurred under increasing threat of foreign involvement in Japan itself, and may have been helped along because of that threat. The Meiji period encountered a crossroads and had to determine the alternatives of going forward into modern civilization or falling back into ancient culture. 31 Western civilization and culture which was oscillating or shaping the Japanese peoples' mind was born out of a scientific ideal and its progress stemmed from this fact, whereas certain time-honored moral concepts served to hinder the development of this very science in Japan. There occurred an unfortunate state of affairs wherein the cultural heritage of Japan was put to a severe test. For example there were rabid innovators proclaiming historical arts of Japan as hopelessly out-of-date and all but worthless. Elise Grille states: (During Meiji 
period) collections of many centuries were scattered, and what could not be readily sold was often broken or burned to make room for the new. In the orgy of foreignism that swept every corner of the nation's life, the arts of Japan seemed doomed to be swept aside and replaced by European models of a type generally considered academic passe' in their home countries. 31 Therefore, not only Tenshin Okaksura but Ernest Fenollosa urged that a stop be put to the wholesale destruction of Japanese cultural heritage. Both of them were concerned about the fate of things about Japan than were many native hotheads. Ernest Fenollosa (1853-1903) was a visiting lecturer during his stay in Japan in 1878; he joined Okakura in his research on Japanese art. Upon returning to America, he served the position of curator of the Asiatic Department of the Museum of Fine Arts in Boston, a position which Okakura later held. The conservation of Japanese value and traditional art in Japan owes much to them. The Meiji Emperor introduced major reforms increasing the importance of scientific, technological, political, educational institutions that were controlled by the central government. Also, the government undertook as one of its first steps to assist in the conversion of business organizations into joint-stock companies. Between 1871 and 1872, the class stratification based on the four classes of society was abolished and the freedom of choice in occupation by all classes of people was recognized. 33 During this 
era, Japan found herself in the process of rapid transition from old to new and the pull between native values and modern values. In the late 19 th century, Japan began to be involved with the bitter struggle which was taking place among the great powers of the world. In the West, at the time, there was a general acceptance in international power policies that great powers had a right to extend their military powers to acquire natural resources by ruling over lesser nations, Japan also began to accept this idea as natural with increasing modernization.

$$
\text { VIII. TAISHO PERIOD (1912 A.D. - } 1926 \text { A.D.) }
$$

This period was not a happy time either for Japan or any of the industrialized nations. Japan was also in a position of playing an aggressive role abroad and the military leaders reinforced their holds on the civil government. A large number of people longed for the emotional security of the old ways. "The ideal of harmony through consensus in a collectivist society seemed attractive, even if the means of achieving it in a pluralistic, modern society were not clear. "34

$$
\text { IX. SHOWA PERIOD (1926 A.D. - ) }
$$

Despite the fact that there was a public sentiment against military power, communications technology which was in the hands of military leaders was used for the object of 
gaining influence and control over the minds, as well as the thinking and perception of the people and finaliy, Japan went into the most tragic period of its history, World War II. Japan learned the lesson that there was very little to be done with military strength. The Japanese people found the term "nationalism and patriotism" distasteful. Some people have maintained that if Japan had a universalistic frame of mind, she might not have taken the road to militarism.

Japan and the Japanese people have taken many paths to self-fulfillment in the world today, however the basic communication patterns which developed early in the Yayoi period are still valid for the most part today. From the Yayoi period to the present, a span of some 2000 years, communication styles, unique to Japan developed through various, influences upon the Japanese people. These styles can be termed either foreign or native depending on whether they developed according to the unique ecological systems of Japan or were brought from China, Korea and other parts of Asia, and modified in Japan. Taken as a whole, they form Japanese culture and Japanese styles of communication.

X. SUMMARY OF HISTORICAL ELEMENTS INFLUENCING THE JAPANESE COMMUNICATION SYSTEM WITH REGARD TO CONSENSUS

Early. Japan was an agricultural, endogamic and matriarchal society. However, as time went on, Japan began to receive cultural inputs from several different areas, nota- 
bly China and Korea. These influences peaked in Japan's Nara and Heian periods with the introduction of Mahayama Buddhism and Confucianism, although their influences were felt much earliex.

The impact of these foreign systems stimulated the Japanese people to accept them, but not before adapting them to fit native Japanese culture. Therefore, although they had foreign origins, they became uniquely Japanese in practice. These philosophical systems had a strong influence on the people and made changes in the communication system in government. In the final analysis, communication systems in the business sphere and throughout the whole of society were no less affected.

The first major noticeable change was the development of a patriarchal basis in society from the original matri- archal basis. Another major change was the increasingly hierarchical basis of society as these changes took place. The glue that cemented this change to a hierarchical system was Confucianism which had developed under the great Han Dynasty. Confucianism institutionalized basically multi-. level society that was made up of superiors and inferiors. The Japanese gave a new twist in that the lower level took care of the upper level, and watched after its interests "whereas in China where Confucianism developed the reverse was true". 35

Thus, a unique system of communication developed which 
has served Japan through the centuries. This system when viewed from the outside was vertical in terms of social stratification with orders being passed down from the top and implemented at the bottom without question. In fact, the communication flow was not downward, just the opposite. An order was initiated at the lower levels and a subsequent decision formalizing this action made at the top. Orders might originate at the top but were modified and converted at the bottom.

In other words "consensus which was introduced from the Tank government system into Japan in 645 A.D." 36 manifested the various levels of a decision making body. The question arises as to how decisions were made at the lower level. The opening article of the Constitution initiated by Prince Shotoku is an example:

...it calls for harmony among different classes in a community... It contains the idea of compromise of reaching agreement on what the ordinary principle, called Li, demands in any case under dispute.

Whether the origin of this consensus pattern of decision making was based upon Buddhism or Confucianism is a matter of great concern to historians. Profession Ryusuke Tsunoda is an example of one who maintains that the origin might stem from Buddhism. At any rate, the Confucianism adopted by Shotuku is considered to be somewhat contradictory to the Buddhist principle. Since the people at the bottom were taking care of those on a higher level, the upper level could not very well force demanding or unaccep- 
table decisions on them. Also, if this type of order was carried out, it could damage potentially those at the top by alienating their subordinates on whom they relied.

In addition, due to the acceptance of Confucianism and Buddhism, harmony, responsibility and hierarchy were stressed. A horizontal and hierarchical class system came into being which emphasized the superiority of one class over another and formalized intergroup relations into an elaborate etiquette. Consensus was the only way the group could function under these circumstances and maintain its outward institutionalized forms.

Another element to consider is that of change within society. As Japanese society evolved and changed in response to the aforementioned foreign stimuli, consensus was the best way to cope with change. A further explanation of this is found in the previous section.

During the feudal period, the emergency of a feuda1istic military regime came to the surface, and as a consequence downward vertical type of communication became apparent. One-way communication from leaders to subordinates lacking consensus was initiated by powerful military leaders. Thus, the more absolute feudal system was applied and a system of absolute despotism reigned. 38 The Tokugawa period provided a transition in society's base. It shifted from a warrior based feudalistic society into a mercantile society. However, again the influence of the traditional hori- 
zontal method of thinking on the part of merchants was strong. The eventual result was the downfall of the strong feudalistic, so-called Sengoku, basis of society and the tremendous rise in the importance and influence of the merchant class. This, in turn, resulted in the re-emergence of consensus, and reflowering of communication from its basically despotical basis into a more consensual basis with some major exceptions.

During the Tokugawa regime, neo-confucianism was manipulated by the Shogunate for the purpose of military discipline as in the case of the way of warrior and class structure called "SHINO KOSHO." During the following Meiji period, Zaibatsu, a Japanese term which refers to a money clique, began to develop a method of decision-making by consensus called "Ringi". This was emphasized to a noticeable degree in government agencies and in large Japanese corporations. (It will be explained in a later chapter.) The emergence of Zaibatsu and Ringi climaxed in the Meiji Restoration. Therefore, the basic factor leading to the Meiji Restoration was the rise of a mercantile class, not the introduction of foreign ships as most historians believe.

The rise of what may be termed the democratization of Japan following World War II changed many outward forms of society. But basic philosophies underlaying Japanese society still permeated the people. The result of this pattern of modernization was evidently felt in the Japanese communication system in government and private industries where a 
return to a basically pre-feudal system occurred. On the one hand, Japan made strides in terms of technology and industry and opened her eyes and interests to the outside world. On the other hand, events, particularly the victory over China in 1895 led to the nationalism and militarism which preoccupied Japan. During the Taisho period, Japan again made an abrupt about face and readopted feudalistic communication patterns for the want of a better term. Following the disaster of World War II, Japan concentrated on rebirth in politics, education, economics and other things. While during the occupation period the power of authoritarianism and paternalism weakened owing to the development of democratization. Democracy was imposed on Japan from outside, though it does appear to have been genuinely accepted, it was reinforced by two conditions, one external, one internal.

In the business community in particular, a new range of communication systems concerning management was introduced through the CCS (Civil Communication of the United States Government), MTP (Management Training Program) and others. In addition, case studies and group discussions introduced from the United States were applied in Japanese industrial corporations. 39 Japan adopted almost entirely some of the American systems in that respect. Nevertheless, the co-existence of eastern traditions and western practices in decision making in government and, of course, in the 
business community has lingered on to the present day.

In the period after World War II, Japanese-American relations began to flower; thus there were massive increases in the amount of communication between the two countries, both in business and government spheres: 
CHAPTER II. NOTES

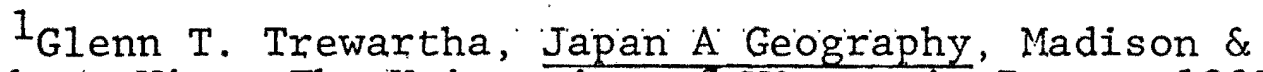
Milwaukee, Wisc: The University of Wisconsin Press, 1965), p. 17.

2 Is ao Kamatsu, The Japanese People, (Tokyo: Kokusai Bunka Shinkokai, 1962 $\longdiv { \text { p. } 4 . }$

${ }^{3}$ Namio Egami, Shumpei Ueyama, Yoshiro Matsuda and Eichiro Ishida, Energy Vo1. 4 (Tokyo: Oct., 1967).

${ }^{4}$ Eichiro Ishida, Pursuing Human Beings, (Tokyo: Kadokawa Publishing Company, 1968), pp. 143-145.

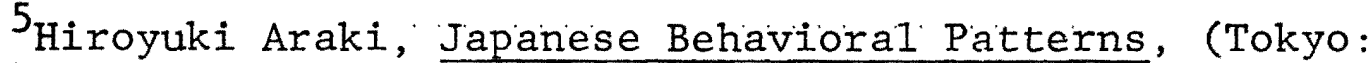
Kodansha Publishing Company, 1973), pp 23-25 \& p. I18.

${ }^{6}$ Scott F. Runkle, An Introduction to Japanese History, (Tokyo: International Society for Educational Information Press, Inc., 1974), p. 6.

7 Mikiko Hane, Japan, A Historical Survey, (New York: Charles Scribner's Sons, 1972), pp. 13-15.

${ }^{8}$ Harumi Befu, Japan, An Anthropological Introduction, (San Francisco, Scranton, London, and Toronto, 1971), pp. 18-21.

${ }^{9}$ Saburo Ienaga, New Japanese History, (Tokyo, Sanseido Publishers, 1967), pp. 13-14.

$10_{\text {Ibid., pp. 14-15. }}$

${ }^{1} 1_{\text {Mitsusada Inoue, Introduction to Japanese History, }}$ (Tokyo: Kokusai Bunka Shinkokai, 1968), p. 7.

12 Jack Seward, The Japanese, (New York: William Morrow \& Company, Inc., $1 9 7 2 \longdiv { \text { , p. } 1 9 2 . }$

13 Hazima Nakamura, "A History of the Development of Japanese Thought, (Tokyo: Kokusai Bunka Shinkokai, 1969), pp. 116-117.

${ }^{14}$ Ibid., p. 94.

15 James Legge, Mencius III A, 4; Chinese Classics 2, pp. $249-250$. 
16Etienne Balazs, Chinese Civilization and Bureaucracy, (New Haven and London: Yale Univ. Press, 1964), pp. 154-155.

17Edward J. Kidder, Early Buddhist Japan, (New York and Washington: Praeger Publishers, 1917), p. 18.

${ }^{18}$ Helmut Morsbach, "Aspects of Nonverbal Communication in Japan," Nervous and Mental Disease, Vo1. 157, (The Williams \& Wilkins Co., 19732, pp. 262-277.

${ }^{19}$ Is amu Kurita, Yuiro Nakamara and Kazuo Morimoto, Logos and the World, (Tokyo: Shincho Publishers, 1971), p. 128 .

${ }^{20}$ Donald Keene, Wm. Theodore De Baryand, Ryusaku Tsunoda, Sources of Japanese Tradition, Vo1. I, (New York and London: Columbia Univ. Press, 1958), p. 59.

${ }^{21}$ Lewin B. Die, Beitraege Zum Interpersonalen Bezug in Japanischen, (Otto Harrassowitz: Wiesbaden, 1969), pp. 18-63.

22 Ibid., Runke, p. 22.

${ }^{23}$ Ibid., Seward, p. 201.

24Edwin 0. Reischauer, The United States and Japan, (Cambridge, Mass: Harvard Univ. Press, 1965), p. 135.

25 Hervert E. Norman, 'Japan's Emergence as a Modern State; Political and Economic Problems of the Meiji Period, (New York: Institute of Pacific Relations, 1940), p. 12.

26 Howard Hibbett and Gen Itasaka, Modern Japanese Reader, Vol. III, Second Edition, (Cambridge, Mass: Harvard Univ. Press, 1968), pp. 31-32.

27 Ibid., Inoue. p. 105.

${ }^{28}$ Komo Toki, Yoshida Shoin Vo1. I, (Tokyo: Iwanami Publishers, 1948), p. 34 .

${ }^{29}$ Hiroshi Nakai, The Structure of Communication, Tokyo: Diamond Publishers, 1974), p.

${ }^{30}$ Edwin 0. Reischauer, Japan: The Story of a Nation, (New York: Alfred A. Knopf, Publisher, 1970), p. 106.

31David A. Dilworth and G. Cameron Hurst, Fukizawa Yukichi's an Outline of a Theory of Civilization, (Tokyo: Sophia Univ. Press, 1970), p. 20. 
32Elise Grilli "Okakura Kakuzo, A Biographilcal Sketch" in The Book of Tea by Kakuzo Okakura, (Rutland, Vermont and Tokyo: Charles E. Tuttle Company, 1956), p. 121.

33Ministry of Foreign Affairs Japan, Japan in Transition, (Tokyo: Ministry of Foreign Affairs, 19752, p. 28.

${ }^{34}$ Ibid., Reischauer, p. 187.

${ }^{35}$ Koji Ishida, The Spiritual Climate of Japan, (Tokyo: Iwanami Publishers, 1974), pp. 50-51.

36 Shunzo Arai, An Introduction of East and West, Japanese Business Management, (Tokyo: Rikugei Publishing Company, 1971), p. 132 .

${ }^{37}$ George Sanson, A History of Japan to 1334 , (Stanford Univ. Press, 1958), p. 73 .

${ }^{38}$ Nobuo Noda, How Japan Absorbed American Management Methods, Modern Japanese Management, (The British Institution of Management, 1970), pp. 52-53.

39 John Whitney Hal1, Japanese History, (Univ of

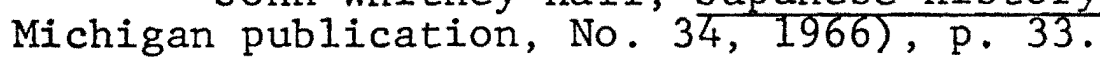




\section{CHAPTER III}

TRADITIONAL JAPANESE CULTURAL ELEMENTS AND SELECTED COMMUNICATION FORMS THAT HAVE BEEN RETAINED

The preceding chapter briefly covered the history of Japanese culture, language and behavior. This chapter will primarily focus its attention on two major elements of the aforementioned 2000 years of history which predominate in present Japanese society and affect communication styles.

The two slected elements are a (1) system of hierarchy which includes the sense of discipline, benevolence, selfdepreciation, non-verbal behavior (use of bow) and verbal behavior and the (2) need for harmony which encompasses vagueness of language, advatism or use of intuition (awareness of other's needs and feeling via non-verbal cues) and the humane sensibility.

As these two major areas are analyzed, it should be helpful for the reader to recall the history behind each element and reasons for its coming into being in order to appreciate the degree to which it permeates modern 20 th century Japan.

\section{A. SYSTEM OF HIERARCHY}

In Japan there still exists a system of hierarchy which is composed of a social layering of society represent- 
ing class structure and systems of values and respect with the higher person at the higher levels of the hierarchy and lower persons attempting to move up through the various levels of society in order to achieve greater social status and respect. This system is evidenced and maintained through several common devices which will be described individually.

\section{Sense of Discipline}

"On" is the Japanese term for a deep sense of ascribed obligation. It is the writer's speculation that an early form of "on" is a Japanese blending of Confuciansim, with its hierarchical forms, Buddism in the Japanese sense of benevolence, and the Japanese character trait of self-inhibition.

A strong case can be made for this when one looks at the different types of obligatory systems. There is still one type due to the Emperor and there are other types such as "on" from children to parents, master from disciples, teachers from pupils and the like. They are all strongly embedded in Chinese Philosophy and found their expression in Confucianism. However, it was not until the appearance of the Tokugawa Shogunate (1603-1867 A.D.) and the advent to power of Tokugawa Ieyasu that "on" came to occupy a vital place. It still enjoys this place today in Japanese society. At the time of Tokugawa, the system of despotism was developed and required a philosophical justification. This justification is found in "on". "On" as it exists today has 
changed from the Tokugawa era. Today's feeling of "on", which is incurred by the inferior because of a superior's action, is of such a nature that repayment of the debt is impossible. ${ }^{1}$ The main type of "on" which exists today is probably that of filial piety, that is the obligation to one's parents for bringing one into the world and for raising one. It is not something that can be taken lightly and of ten times an individual's behavior will be, to a great degree, shaped by this obligation. Throughout life, one must respect and obey his or her parents in order to repay this deep indebtedness. There is a well known saying in Japan that "Debt of 'on' toward one's parents is deeper than the ocean and higher than the mountain". ${ }^{2}$

"Giri" is a prescribed obligation, but unlike "on" can be repaid and erased by an exactly equal repayment within a prescribed period of time. However, as long as it exists, it can never be forgotten. "Giri" is usually a debt between equals but also could be from an inferior to a superior. ${ }^{3}$ Because of the hierarchical systems in present day Japan, an inferior could not give a gift to a superior except as a return on the superior's gift.

"On" and "giri" also find their place in the Japanese business world. It has often been said that Japanese companies are like a large family, even in large firms which enjoy business on a world wide basis. They find their expression in such uniquely Japanese practices as life-time 
employment, the seniority system and a totally paternalistic organizational structure.

Another way that "on" and "giri" affect the operation of the Japanese business world is by intimidating those in lesser positions in the company establishment from openly speaking up or disagreeing with a superior. Should he do so, he could be accused of being a person who does not know "on" and "giri", a serious accusation in Japan. It should be mentioned that the superior had undoubtedly provided much needed help and necessary moral support previously, thus giving the inferior a debt of "on", a permanent fixture of their relationship. ${ }^{4}$

A review of the various categories of the obligatory systems follows. 5

A. "On - it is ascribed obligation possibly incurred.

a. On received from parents.

b. On to one's master, boss, teacher, mentor and the like.

c. On received from Emperor (particularly before World War II).

d. On received from all contacts in the course of a life time.

B. "Giri" - The debt must be paid with mathematical equivalent and then it no longer exists. "Giri" is apparently Japanese and results from a blending of Confucianism and Buddhism. 
1. Giri to the world or public as a whole. The term "sekentei" (one's face toward public or society) and "suji michi o tosu" (the way one must take steps; stem largely from this concept.

a. Duties to relatives outside the immediate family.

b. Duties to non-related person due to "on". received as a gift or favor for work contributed.

2. Giri to one's name. The term "rashiku", "one as it should be" springs from this concept.

a. Duty to clear one's reputation of insult or implication of failure.

b. One's duty, to admit no professional failure or ignorance.

c. Duty to observe respectful behavior not living above one's station in life, curbing all displays of feeling of inappropriate condition.

3. "Gimu" - It refers to proper and fitting behavior of the payment of the obligation. One example is that one must play the role one is assigned in life positively.

a. Loyalty to the Emperor (particularly before World War II) law and country.

b. Duties to parents and ancestors, the Emperor (particularly before World War II) and one's work.

c. Time limit is forever.

d. No more than partial payment is even possible.

e. Gimu is also found in China. 
A Japanese psychologist, Dr. Hiroshi Minami, enlarged upon the above stated discussion as follows:

"Giri" carries various implications in the Japanese language. It is considered to be a sort of convention through which one is required to behave as he should according to circumstances or in any interpersonal relationship...unlike "gimu", "giri" does not support legal rights. 6

Both "on" and "giri" strongly support the hierarchy

system in Japan.

Benevolence

A feeling of benevolence on the part of the superior in Japan is one of the basis of "on" and the person who shows benevolence to his inferior can always expect that the debt of "on" will be owed him. It is thought that benevolence began to develop in Japanese society with the importation of Buddhism, even though Buddhism in China did not attach much importance to it. Nevertheless, there is no single reference to the work in either of two great early Buddhist works "shin-jin-mei" (the Epigram of Faith), and "shodo-ka" (the Song of Enlightenment): 7

This new element found fertile ground for development in Japanese society and has continued to grow in importance. The advent of the significance of "on" gave benevolence a greater priority because it prevented the superior from taking undue advantage of his subordinates while at the same time rewarding his good behavior by establishing debt of "on" in his favor. 
"It must be noted that benevolence is to be extended not necessarily as the expression of genuine kindness or sympathy, but as a formal justification of superior status." 8

\section{Self-Depreciation}

Self-depreciation entered Japan at a very early date and most probably has a Chinese origin. It is the element which leads most Westerners to comment on the great politeness and modesty or reservation of the Japanese people. 9 Self-depreciation serves as a device for self-protection, for the lact of a better term, against breaking the rules of decorum. In order to be sure that one is not ignoring "on", assuming a superior's role, individuals may intentionally depreciate their role. Their help and contributions, of course, are still recognized for what they are worth but they themselves are forbidden by etiquette from publically admitting their achievement.

The way in which we have been discussing thus far is evidenced through a sense of discipline, benevolence and self-depreciation. Here, an attempt will be made to illustrate some of the communication behaviors which spring from the element of a system of hierarchy.

Non-verbal Behavior: Use of Bow

In Japan, the bow is more than a simple formality. It is an absolute social necessity. One of the first things that Japanese parents teach their children is how to bow 
properly. $*$ The extent and depth of a bow points out the person's status in relation to whoever he is bowing to. And in fact, if one were to look at the average Japanese in a telephone booth talking with someone, perhaps, 100 miles away, one could still see the person bowing as the conversation comes to a close. This use of the bow signifies respect and is one of the clearest indications of a person's upbringing and manners. It is vital in all social situations between all individuals no matter how low or high their position in society like Chinese kotow.

\section{Verbal Behavior}

Another type of Japanese communication behavior is found in the unique way in which language is utilized to establish different levels of status and formality. $* *$

The Japanese language which belonged to the Ural-Altaic family underwent a fundamental transformation with the massive importation of Korean grammatical features (vowel harmony, word order) and the introduction of the written Chinese language (pictographs, diagrammatic and composite characters) and Chinese thought during the reign of Prince Shotoku. It was at this time that the hierarchy in Japan was beginning to crystalize and the introduction of these linguistic elements, evidently speeded that process. 10 Up

* For more information, see Appendix III. $* *$ As for the level of formality, see Appendix II. 
until Prince Shotoku's reign, there was no clear and easy way to distinguish the position of people in society through the use of the common language.

The importation and subsequent molding of the written Chinese language provided this method in the following manner. 11 "Depending on the situations or occasions, a person's status, etc., one manipulates an entirely different set of expressions"12 by substituting the suffix, prefix, verb endings and so on. No matter how polite the tone, the choice of verbs, special nouns and pronouns depict immediately and completely the position of individuals who are speaking.

By way of example, the pronoun "you" has approximately 16 different derivative translations such as "kimi", "anata", "omae", "otaku", "onushi", and others that can still be found in Japan at the present time. ${ }^{13}$ Thus, each different form of the word "you" indicates the social position and role relations of the listener in the eye of the speaker and the personal proximity between the two.

To use the wrong format at this time, can result in a mortal insult to the person being spoken to. Because of the problem in determining exactly what language to use, there is a likelihood that many Japanese feel uneasy facing situations in which he or she must meet people for the first time.

Unless the social status, age and other relating things of each other is cleared up in the first meeting, both par- 
ties feel insecure and often uncomfortable. It may stand in the way of freer self-disclosure as well as communication. Therefore, the use of name cards is recognizably encouraged once one goes out into the world. It gives us an index of which level of language to use, how to behave and so on so that both parties feel secure later. Without consciousness of establishing ranking order, life could not function smoothly, because establishment of rank is the social norm on which life is based in Japan. Once the ranking order was established in the first meeting, it would last forever and it could be applied to all circumstances.14 The opposite case is true in America.

There are also approximately 8 different forms that refer to children, students and servants which also show the relative status and the social position of the people being spoken to or about. The Japanese language also includes the use of formal levels of honorific and respectful terms which imply ranking within and outside a family. Even now, there are 9 expressions which signify mother and father. In the case of a wife and son, 11 are found. There are 7 for husbands and 9 for daughters. All of which, evidently, tell different levels of intimacy or respect between the two parties.

* The term "servant" is replaced by house keeping helper in terms of euphemism in the Japanese sense of the word. 
The writer also should like to mention that the type of speech a Japanese male will use is entirely different from that of a female. The type of speech that men have traditionally used in Japan has been mainly of Chinese origin, which tends to be blunt, more to the point and slightly less formal. Women in Japan use a very stylized and routine form of the Japanese language that indicates their femininity and their tranditional status as inferiors.

These different forms were developed by the Japanese people from the Korean grammatical features and the Chinese language. Many points of similarity are found between the Korean language and Japanese language in terms of common words as to agriculture, industrial arts and vowels even during the late Jomon period. The word order in Japanese is entirely different from that of Chinese although efforts were made to Japanize the Chinese sentences and characters. The higher status groups used a Chinese approach, thus creating a clear dichotomy between the two. As time went on, the necessity for further clarification of status was thought to exist.

The use of apology is another verbal behavior stemming from the attitude of self-depreciation. Mr. Sho G. Dozono, a lecturer in Japanese once stated: "The use of apology is also a distinctively Japanese form of expression."16 In the Western context, apologies are generally used to signify repentence or sorrow over one's own actions 
or another's misfortunes. However, in Japan the use of apology is far more widespread and carries far less emotional weight. An interesting case is evidenced by the fact that the Tokyo Giants, professional baseball team, could not elinch the pennant and made the worst record for the 1975 season. Not only the owner but the manager and all the players decided to apologize for the record in the presence of fans after the final game. The apology is used in Japan not only to express the aforementioned circumstances but also when one wishes to ask for something, when one receives favor and feels that another has gone to some trouble over them, when one feels embarrassed over a given set of circumstances, or when one finds oneself in a difficult position.

This use of apology is deeply rooted in Japanese history and plays an important role in Japanese interpersonal communication today. However, the use of apology by Japanese Whould not be considered in all cases to be the same as an apology in the Western sense. Rather often it serves only as a means to preface a request.

The Japanese language since the days of the Nara period was simplified a great deal with the invention of two ways of reading called "on-yomi" and "kun-yomi" along with "hiragana" invented by a monk, Kobo Daishi during the 9th century and "Katakana" by Kimino Mabiki during the 8 th century. Toward 1935, Yuzo Yamamoto began to show a deep interest in simplifying the Japanese writing system, and he 
played a leading role in the language reforms carried out after World War II. 17 Yet many of the elements that were modified during Nara and Heian periods are still valid today. For-example, it has been said that an individual must learn that when one talks to a person who is older (superior, friend, inferior, etc.), some specific and particular verbs, nouns, and pronouns need to be selected. In addition it was Prince Shotoku who presided over the elements mentioned above, and the introduction of a very flowery sort of talk that is largely confined to the court.

The communication behaviors that have been covered thus far shaped certain characteristics. There are elements of etiquette which manifest levels of formality, status, superior and inferior relationships and thereby reinforce the existing social hierarchical structure of Japan. Another characteristic that they share in common is that they are by and large of Chinese origin and molded to fit Japanese circumstances and Japanese culture.

\section{B. NEED FOR HARMONY}

The second major cultural element that comes from ancient Japan is the strong need for harmony.

The elements to be covered go beyond mere formality and hierarchy into the very basic of Japanese thought. They provide the feeling of solidarity and enforce the group concept that we have concerned ourselves with for the most part 
of this paper.

The need of harmony which was stressed in Chapter II, arising from the peculiar ecological condition of wet rice cultivation, has not changed in Japan. Primarily, because Japan has a very dense population and extremely limited land resources to support that population. A high degree of cooperation and lack of friction and confrontation is required for the smooth functioning of society. 18

The ways that communication has aided the sense of harmony in Japan will be discussed.

Vagueness of Language

Vagueness, especially the absence of negative language, is one way of element that enables Japanese people to maintain such a high degree of harmony. There is no word in the Japanese language for the Western dialectic type of "No". 19 Instead more vague and round-about terms must be used to express negative ideas and to preserve the relationships between individuals. What Japanese people have developed is the technique of suggestion or implication known as "Honomekasu" in Japanese. In addition, it is worth noting that as some of the readers who studied Japanese can recognize, predicate comes before the verb in Japanese. This means that one cannot keep tract of where the speaker stands if he can hear the whole sentence. A psychological merit will be given to him when he can shift gears and his position in 
anticipation of the speaker's reaction to it. But there will be a case that one is left wondering whether the speaker really means what he mentions. This vagueness of language is likely to prove a major pitfall when used with persons from the United States and elsewhere. It is this vagueness of language, the absence of the word "no" and the reluctance to express ideas contrary to the wishes of the guest or of the majority which leads to misunderstanding.

A case in point were the summit talks between President Nixon and Prime Minister Sato. To a question raised by President Nixon, Prime Minister Sato replied by saying, "I'11 take care of it". What he actually meant was "I'II do my best to find a solution". His desire to avoid friction was interpreted as an indication of his willingness to go along. This was merely a desire on the part of the Japanese government to avoid offending the American government, much as the Japanese government would have done with any other power. 20

This vagueness of language has perhaps, been a factor in Japan as early as the Yayoi period. It has undoubtedly caused countless misunderstandings not only between Japanese and abroad, who either did not understand the cue or who wanted the dialectic "Yes" or "No" answer, but also perhaps between Japanese and Japanese. This vagueness of language is one of the major fundamental differences between America and Japan as far as communication patterns are con- 
cerned. It is based, like all other communication differences on culturally conditioned ways of living and thinking such as have been reported in the previous chapter. Karl Pribram stated his view on the importance of thought patterns as follows:

Mutual understanding and peaceful relations among people of the earth have been impeded not only by the multiplicity of language, but to an even greater degree by differences in patterns of thought - that is by differences in the methods adopted for defining the sources of knowledge, and for organizing coherent thinking -- the most striking differences among philosophical doctrines are attributable to deep seated divergencies in the methods of forming fundamental concepts and of defining the functions of reason - that is, the cognitive power of the human mind and the extent and validity of that power. 21

The Western mind which embodies a dualistic Yes or No approach simply cannot comprehend the Eastern mind which people in the West regard as illogical and which basically tends to be advatistic.

The Japanese, on the other hand, might regard Westerners as vulgar for obvious displays of over ambition when they presume to give direct replies.

Advatism or use of Intuition

Advatism asserts that reality is non dualistic. It leaves questions open and refuses to make any definite statement about the outcome. Advatism has its foundation in Zen Buddhism. It can be said that advatism. is neither black nor white, it is instead a permanent state of grey. It can be both "Yes" and "No", but at the same time, neither 
the one nor the other. 22 This advatism is another element of the Japanese communication and thought procèss which creates an extremely difficult climate for thought to develop between Japan and the West and which makes even the use of interpreters of doubtful value.

While the interpreters might be able to translate the specific words being spoken or ideas coming across, it is doubtful that more than a handful of Western statesmen, businessmen, government officials, or others would have the knowledge or background to appreciate or use the information being given him and very likely he would misunderstand completely what was being said even though the basic interpretation was accurate. This sort of advatism is closely tied in with the place of Rinzai Zen in Japanese life. Rinzai Zen stresses a non-verbal and initiative approach to perception. Rinzai Zen regards verbal communication to be the ultimate in frivolity. In contrast to this, the Holy Bible Red Letter Edition by King James stresses, "In the beginning was the word, and the word with God, and the word was God. AlI things were made by him and without him was not anything made that was made". As previously shown, Rinzai Zen came into Japan in the 13 th century and was quickly adopted to Japanese needs. It may be interpreted that this rapid acceptance is due to the fact that it fit almost exactly what the Japanese thought the pattern needed at that time. ${ }^{23}$ This Rinzai Zen which might be looked upon as one of the 
highest and most difficult philosophies in the world to comprehend found a ready acceptance ritualistically among all levels and all classes of Japanese people and created a deep undying influence that has lasted up until the present time.

An understanding of its emphasis on intuition throws some light on the Japanese reluctance, or distaste for the spoken word. This is carried to such a point that spoken assurances of sincerity often leave Japanese listeners with the feeling of insincerity - a source of stumbling block in United States - Japanese communication. Hidetoshi Kato states :

If we talk, we can understand. If not, we can't understand is a principle of communication in America. In Japan, the opposite case is true. The principle is even if we talk, we dog't understand. We can understand without talking. 24

Rinzai Zen was accepted totally as it was and established the influence it did, because it provided the Japanese people with a justification for remaining tacit and reticent and thus, avoiding any possibility of public misunderstanding. To be sure, the possiblity for private misunderstanding is greatly increased. This non-reliance on the spoken language creates a situation in which intuition "Sassuru" or "ichi o yuwarere Ju o shiru" comes to play a vital role in interpersonal communication. 25

In fact, the intuitive ability of a manager to read or sense instinctively the feeling of his subordinates and 
their needs, and to act in such a way that others in the organization will not be offended is his most important role. It is, generally, the primary qualification for a Japanese leader at whatever level to possess. 26 This use of intuition develops out of a very real need to be aware of other's needs and feelings via non-verbal cues and to realize what others are thinking by use of a process other than verbal communication. This is no less important today than it has been in the past, perhaps even more so. This directly clashes with an American reliance on straightforward and argumentative types of languages.

To further clarify differences in the two systems, consider the type of individuals chosen for manager in the two systems directly reflect these cultural values. The American manager must be self-expressive, straightforward and willing to take chances as well as anxious to put his own ideas to the forefront in order for him to advance. A Japanese manager, on the other hand, should be the direct opposite of these things (of course there are some exceptions). There is a tendency among Japanese managers to avoid confrontation with all parties, and be sympathetic with his subordinates to a degree unknown in an American company.

According to Professor Harada who has conducted a first hand survey observing managers both in leading private firms and in several Chamber of Commerces states, "A Japanese manager generally by nature, must be non-aggressive, and if 
he wishes to advance for, does so by listening rather than talking excessively, and by accepting others' ideas than putting his own ideas forth."27 An American manager in a Sony Corporation plant in America comments, "You get a feeling around here that they care about people, whereas in my previous work experience with United States companies, they cared only about output and meeting the profit projections. "28

Japanese superiors must also be people whom the subordinates can depend/and are endeared by the subordinates. The manager in Japan must show them warmth and kindness, becoming in effect a second father, creating a community of feeling. At the same time, there is the position in which their personalities are judged or evaluated by their subordinates. A leader, then, exists in more a familiar relationship and he knowingly discourages remoteness with his subordinates.

It has been statistically proven that employees vastly prefer the hard master who shows interest in their personal affairs rather than the lenient boss who minds his own business. However, as Professor Nakane suggests, "One of the characteristic features in the operation of this system is that the weakness of the superior may be covered by his subordinates and vice-versa."29

In this system, the man at the top does not have to be intelligent or capable. If he is outstandingly efficient 
in handling his matter, it results in depriving the man below him of losing a part of his important function or having a high batting average, so to speak and they may edge away from him. (This type of inter-relationship is clearly demonstrated in the decision-making process which will be covered in the following chapter.)

The place of the obligatory system previously touched upon, plays a part in this relationship between supervisors and inferiors. For instance, in order to show kindness and favor on the inferior, the superior goes to his subordinates' wedding ceremony, serves as a go-between for marriage, makes speeches on important occasions, and helps out in an emergency, etc. The inferior then develops a debt of "on" to him and when asked for extra help or special efforts, quickly complies.

Ninjo (The Humane Sensibility)

"Ninjo" is an understanding response to another's hidden feelings of deprivation and is generated between two individuals in a private setting.

At times, the inferior inevitably experiences emotional frustration or personal anguish, but as long as the relationship between the two runs smoothly, the superior is expected to understand the inferior's suppressed anxieties and frustration, and to extend his empathy. This function of the superior is called Ninjo (humane sensibility). Masataku 
Sugi explains that Ninjo is slightly different from sympathy and kindness as understood in the West. The essential differences lies in the fact that Ninjo is an understanding feedback or response to another's hidden feelings of deprivation or despair. 30 Ninjo exists, in the depth of private feelings, and it is to be subordinated to "giri". or formal obligations and duties. One is supposed to fulfill his obligations at all costs, and "ninjo" must not interfere in any way. In no sense, therefore, does Ninjo alone on the part of the superior release the fulfilling of the inferior's obligations without denying the inevitability of his obligation, the superior tries to extend empathy and understanding, to assist him in the fulfillment of his duties. Therefore, Ninjo is evoked or generated between two individuals in a private and intimate social relationship.

This relationship is cemented by the desire of Japanese to psychologically return to the unpressured spoiled days of childhood where someone would always take care of his needs. This psychology is known in Japan as "Amae", and the relationship might be termed a two-way dependency relationship. Thus, the superior sustains the inferior and at the same time, the inferior provides the necessary favors and work, helping the superior to advance to his position of social hierarchy.

The motivation of the Japanese people to willingly and voluntarily obey others and comply to a strict code of con- 
duct is remarkable in view of the fact that traditional Japanese society lacked a universal code of ethics from a religious basis. Neither did it encompass any definite concept of sin. Unlike Christianity, none of the three religions practiced in traditional Japan offered either a moral basis or unequivocal ethical instruction as guides for daily life. Instead of these, the concept of shame was substituted and served to enforce a particularistic ethical code and rigid adherence to specific rules of conduct. In contrast. to universal ethics, situationally-oriented ethics is being used by some scholars. In addition, in the Western world, individualism is thought to be the basis of ethics. But in Japan, the removal of conflict between different individuals was considered to be the ethical ideal.

\section{AGREEMENT BY CONSENSUS}

Directly related to the need for harmony is the Japanese method usually employed for reaching agreement consensus.

This chapter presents a description of the traditional consensus method of reaching agreement which stresses nonverbal aspects and the modern day method which encourages the verbal communication.

Peter Drucker once remarked, "If there is one point on which all authorities on Japan (agree) . . ., it is that Japanese institutions, whether business or government agen- 
cies, make decision by consensus." 31

The consensus type of decision making, particular to Japan, has taken several forms throughout Japanese history. However, the form that is prevelant today found its origins in the aftermath of World War II, and represents some of the ideas that the American occupation of Japan was designed to cultivate. Like most of the reforms of American military establishment in the past era, the Japanese changed the preferred American method of reaching agreement to fit their own styles of communication.

Just as the earlier importation of Confucianism and Buddhism was molded to fit the Japanese model and circumstances, so has the so-called democratization of Japan been molded to fit Japanese values and Japanese culture. Thus, democracy as it exists in the West, does not exist in Japan. It is a matter of semantics. In America, democracy is on the individual basis, whereas in Japan democracy is on a group basis. Thus, the fundamental basis of Japanese decision making has not changed.

The guiding spirit of decision is still concord or harmony and the goal is directed toward cooperation and consensus. $^{32}$ One of the Japanese methods of maintaining harmony in decision making, which is gradually dying out at the present time, is referred to as "Ringi". Rin is translated as a proposal submitted by a subordinate to a person at the right top and obtains approval and gives means delib- 
erations and decision.

Ringi as a system was developed under Prince Shotoku and refers to $a$ blend of traditional family systems and total group mobilization which upheld the value of consensus and mercantile ideal of making a profit. It lost popularity in the feudal period but was revived during the Meiji Restoration and its importance increased until the end of World War II, and the advent of the American occupation.

American policy regarding the advancement of Japan launched a 180 degree shift with special emphasis on demilitarization and the American way of democratization. But this affected "ringi" very little. The system still functions much as it did under the reign of the Meiji Emperor.

The decisions made under this system must go through a rather formal and lengthy operation. The first step might be termed the encouragement of the idea. During this phase, the manager encourages ideas and comments from the lower levels of the organization. 34 The manager, therefore, must be an individual practiced in the art of mediation, whose primary value rests with his ability to get along with people, be a mind reader, and also foster cooperation and good feeling in the organization. One looks on him not so much as a boss, rather a substitute father.

Once an idea has been developed by someone lower in the organization, the second phase of the decision making process is initiated. Mr. Ninomiya, a manager of Western Grain Company commented, "During this crucial stage, the 
idea in the written form is passed among the various sections of the organization where each individual in that section must approve it with a stamp or disapprove it with comments."35 Should there not be unanimous agreement, the idea will be sent back to its originator who can either compromise and change the objectionable parts of this plan or if there is a great degree of opposition, he will shelve the plan.

After each subordinate has affixed his stamp of approval to that idea, it will then go to management where the formal decision will be made. It will almost always be approved by top management which has the honor of signing the idea into action and taking the major credit for it.

The Ringi method of the decision making process is now beginning to fall into disfavor among some of the Japanese cooperative structures. ${ }^{36}$ This is because recently, the system has become incongruent with the new and intricate demands placed on big corporations by the changing environment and rapidly changing economic conditions. Primarily a formality, its major function in these companies today is for record keeping.

Current systems of decision making in Japan were developed out of the American occupation. Under this system, the idea originates on the same levels and for precisely the same reasons (encouragement from the above) as the ringi system, but has one major difference. Whereas the ringi 
system is for the most part non-verbal, reliance is heavily based upon intuitive knowledge. 37 Now a verbal exchange of ideas is encourgaed. Under this system, according to $\mathrm{Mr}$. Ishiguro, a manager of the Tokyo Bank in Portland, "Before a formal decision is made by the organization, informal discussions are held among the individuals concerned and opinions exchanged and adjustments will be made until consensus has been reached."38

Should consensus prove impossible, the idea will be dropped. However, should consensus be forthcoming, the idea is passed on to the formal organ which approves the decision more as a formality than anything else. The decision making method employed by the contemporary Japanese business circles, then, rests entirely on small group discussion among members in the many organizations.

It is evident that much time is required for decision making since consensus must be reached. However, once that decision is made, the total cooperation of all members of the group can be expected since the will of the group is reflected in the decision.

Should an individual in the group object to the idea on whatever grounds, and find himself a lone objector or in a small minority, he will change his formal opinion, called the principle (Tate mae), to one of the approved ideas even though his true or real mind and idea (honne) might be opposed to the plan under consideration. When they express 
opinions or comments disagreeable to others, they show their hesitancy by manipulating vagueness of language or retract themselves. He does this not only for the welfare of the group, but for the sake of his position in the group.

It is believed that unanimous agreement plays a vital role in social function for Japanese. In this light, Doi states:

It is a token that the maturity of all the members has been preserved. In other words, it is a token satisfaction of Amae (psychology). For Japanese hate to contradict...., they don't want to have divided opinions in the first place, if such an outcome turns out to be inevitable, they get so heated and emotional that it becomes impossible to have reasoned discussions. 39

In the writer's view, what he is overlooking in his explanation is the philosophical aspect of the Japanese mode of thought in both advatism and Japanese postulational thinking.

Thus, an individual must occasionally sacrifice to maintain his position in the group. One of his strong values is to be a desirable group member. The Japanese tradition of judging social relations in the Yayoi period reinforces this. Even a person at the management level conforms to the popular view. To cite an example, the Japanese vice president of a major Japanese bank put the idea in this fashion, "Many people review a decision so it is very difficult for a manager to be arbitrary. We try our best to persuade others, but if the others disagree, we think, maybe, my 
idea is wrong after al1."40 Thus, the manager who disagrees with a proposal often remains silent rather than upset the relationship he wishes to maintain with his subordinates.

The traditional cultural and communication forms are reflected in the decision-making.process. Individuals desire to remain a part of the Japanese cultural system, thus sacrifice to the group. Loyalty is perhaps, the single most decisive factor in the decisions made through the group.

The aforementioned elements which have come through history provide this system of decision-making. 
CHAPTER III NOTES

' John Whitney Hall \& Richard $\mathrm{K}$. Beardsley, Twelve Doors in Japan (New York: McGraw-Hill Book Company, 1965), p. 94 .

2Howard Hibbet \& Gen Itasaka, Modern Japanese, A Basic Reader, Vo1. II (Cambridge, Mass: Harvard Univ. Press, 1974), p. 31.

${ }^{3}$ Ibid., Hibbitt and Beardsly, p. 95.

${ }^{4} R$. D. Dore, City Life in Japan-A Study of a Tokyo Word (Berkeley, Calif., Univ. of California Press, 1958), pp. 262-268.

${ }^{5}$ Chie Nakane, Conditions for Adaptation (Tokyo: Kodansha Publishers, 1972), pp. 148-158. Ruth Benedict, The Chrysanthemum and the Sword (Cambridge, Mass: Houghton Mifflin Company, Boston, 1946), p. 116.

${ }^{6}$ Hiroshi Minami, Japanese Psychology (Tokyo: Iwanami Publisher, 1960), pp. 186-197.

7Hajime Nakamura, A History of the Development of Japanese Thought (Tokyo: Kokusai Bunka Shinokkai, 1969), pp. 121-122.

8 Masataka Sugi, "The Concept of Ninjo", in John W. Bennet and Iwao Ishino, Paternalism in the Japanese Economy: Anthropology Studies of Oyabun - Kobun Patterns (Minneapolis: Univ. of Minnesota Press, 1963), p. 286.

9John Haylook, "My Impressions of Japan" in Japan as Others see Her (Tokyo: Genshobo, 1972), pp. 21-23.

${ }^{10}$ Lewin B. Die Geschiehtliehe Entwieklung des Japanischen Soziatius. In Lewin B. Die Beitraege Zum Interpersonalen Bezugin in Japanishen (Otto Harrassowitz Wiesbaden, 1969), pp. 16-68.

${ }^{11}$ Tadao Miyamoto, Language and Contemplation (Tokyo: Heibon Sha Publisher, 1974), p. 39.

12Yoshio Kuze, Mijikana Nihongo (Tokyo: Asahi Sonorama Inc., 1975) pp. 55-56. 
${ }^{13} \mathrm{~L}$. Hearn, An Attempt at Interpretation (Tokyo: Kenkyusha Publisher, 1975), pp. 197-198.

14Chie Nakane, Japanese Society (Berkeley and L.A.: Univ. of California Press, 1970), pp. 30-31.

${ }^{15}$ Gen Itashaka, Nihongo Yokocho (Tokyo: Shibundo Publisher, 1974), pp. 120-143.

16Private Interview with $\mathrm{Mr}$. Sho Dozono who holds chairs in Japanese Language at Portland State University.

17 Ibid. Hibbet and Itasaka, p. 56.

18 Discussion: Japanese, Chinese and English with Stewart H. Schener in Nihon Hoso Kyokai English TV Program, Oct. 31, 1972 .

${ }^{19}$ Louis Kraar, "Japan is Opening Up for Gaijin Who Know How" in U.S./Japan Outlook, Volume 4. No. 2, San Francisco, California, Japan Trade Center, 1975, p. 19.

20 Jack Seward, The Japanese (New York: Morrow \& Comapny, Inc., 1972) pp. 177-178.

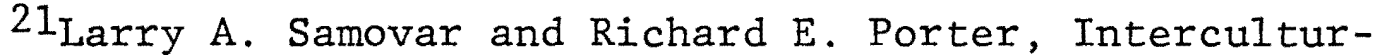
al Communication: A Reader (Belmont, California: Wadsworth Publishing Company, 1972), p. 11.

${ }^{22}$ Yoshio Abe, Dialogue with West (Tokyo: Kawade Shobo, 1972), P. 13 and Charles A. Moore, Japanese Mind (Honolulu, Hawaii: East West Center Press, 1972), p. 63.

${ }^{23}$ Ibid., Japanese Mind, p. 16.

24Hideyuki Kato, "Why Don't We Ta1k?" in Language Life, Volume 11, Tokyo, 1961.

25 Hajime Nakamura, Way of Thinking of Eastern Peoples (Honolulu, Hawaii: East West Center Press, 1964), p. 575.

${ }^{26}$ The Mainichi Daily Newspaper (Tokyo, Feb. 20, 1974).

27Private Interview with Professor Fujio Harado of Chuo University, held in Portland, Oregon, Aug. 28, 1975.

${ }^{28}$ Richard Tanner Johnson and William G. Ouchi, "Made in America" in U.S./Japan Outlook, Volume 4. No. 2, San Francisco, California: Japan Trade Center, Spring, 1975, pp. $2-3$. 
${ }^{29}$ Ibid., Nakane, Japanese Society, p. 65.

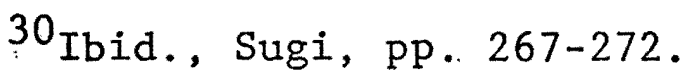

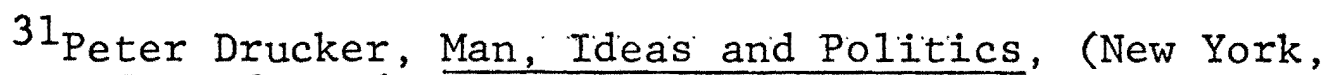
Evanston, SF and London: Harper and Row Publishers, 1970), p. 202 .

${ }^{32}$ Howard F. Van Zandt, "How to Negotiate in Japan in Intercultural Communications: A Reader, (Belmont, Calif: Wadsworth Publishing Company, 1972), pp. 266-267.

33Herbert Passion, The United States and Japan, (Englewood Califfs, N.J.: Prentice Hall, Inc., 1966), pp. 30-31.

${ }^{34}$ Susumu Takamiya, Background, Characteristics and Recent Trends in Japanese Management, (London, England: The British Institute of Management, 1970), pp. 99-100.

35 Private Interview with $\mathrm{Mr}$. Y. Ninomiya, held at Western Grain Company in Portland, Oregon, July 28, 1975.

${ }^{36}$ Ibid, p. 102.

$37_{\text {Kogi Kobayashi, "Recognition of Management and }}$ Technology" in Management Japan, Vo1. 6, No. 2, Autumn, 1972, p. 19.

38 Private Interview with $\mathrm{Mr}$. Ishiguro, a manager of Tokyo Bank, Ltd., Portland, Oregon, August 13, 1975.

${ }^{39}$ Takeo Doi, "The Japanese Patterns of Communication and the Concept of Amae" in the quarterly Journal of Speech, Volume 59, No. 2, (April 1973), p. 184.

40 Richard Tanner Johnson and William G. Ouchi, "Made in U.S.A." in U.S./Japan Outlook, Volume 4, No. 2, (Spring, 1975) Japan Trade Center, p. 6. 
CHAPTER IV

U. S. DIALECTIC METHOD OF REACHING AN AGREEMENT

In contrast to the method of reaching an agreement through group consensus, American groups and organizations usually put emphasis on the dialectic approach which is diametrically opposed to the Japanese method. Dean Barnlund states it clearly:

In the United States, problems are sharply defined, causes of difficulty identified, alternative proposals offered and challenged, descisions hammered out through a process of argument and compromise. In Japan decision-making follows a different course. The discussion may proceed at some length without any clear. specification of the problems. Participants proceed cautiously, attempting to decipher the opinions of others without asking them directly. Variation of views are intimated but so expressed that they can later be qualified or retracted if they encounter resistance. 1

In an effort to gain a greater appreciation of the dialectic method so that it can be contrasted with the consensus type method of Japan, primary attention in this chapter will be focused upon the following subject areas: (1) definition of dialectics; (2) some selected factors which have contributed to the creation of the American approach to decision-making and (3) a series of interviews which should illustrate the dialectic method of decisionmaking as it contrasts with Japanese method of consensus. 


\section{DEFINITION OF DIALECTICS}

"The term dialectic originates from the Greek expression for the art of conversation."2 Byron Haines, a professor in philosophy describes dialectics thus: "A conversation goes forward by assertion and denial, also compromise, changing or defeating opposition."

Dialectics can be defined for our purpose as the logical sequence of reasoning leading to the best possible. conclusion, utilizing the dualistic approach and deciding on a course of action by first examining the probable consequence of any other action and of that action. The dialectic approach then utilizes as a central theme the poles of absolute correctness and absolute falsity. It enforces what we might call a black and white approach by looking at two different hypotheses and choosing through logical reasoning the one which is better or correct. ${ }^{3}$

Conflict is a direct result of the dialectic method of decision-making in that by utilizing the dialectic approach, conflict is not only desirable but necessary in order to reach a good conclusion. 4 Conflict arises from the presence of a devil's advocate, so to speak, in most decision-making processes, and from each side's tendency to view its position as the best, if not the only possible one. 
In order for the worth of one position to be made clear, it is desirable to have a conflicting and opposite approach put forward. Conflict also fits in with the single major characteristic of modern management organization; that is, its diversity. Because of the dynamic and complex nature of modern organizations, a selective rather than unitary approach is imperative in making a good decision. ${ }^{5}$ Because of this aspect of American business organizations, we would almost need to anticipate disagreement among the various segments. 6

This is in direct contrast to the Japanese system where a high value is placed upon conformity between organizations and groups which make conflict undesirable rather than productive. In this regard, George Nakata, Deputy Director, Trade Development of Port of Portland, made a few remarks :

If you have a conflict with your fellow employees, either subordinates, peer level or superiors, the environment in American business circles, generally dictates an open-mindedness in hearing different alternatives, different dimensions and other choices which may be better for the overall strategy than your own opinions. Therefore, generally, I think conflict and other views are most welcome and $I$ think it is healthy and positive. 7

Further illustrations of the paramount position of conflict in American groups can be seen in the manner by which individuals join in groups or societies. Edmund Glenn says in effect that American persons normally expect to be able to exert reasonable influence in selecting the pro- 
cedures of groups. They do so in order to accomplish their expectations. 8

The writer hopes that the above paragraphs will give the reader a basic understanding of his use of the term "dialectics" and its relation to conflict. By referring to the earlier chapter on the Japanese method of working in groups, a clear difference between the American and Japanese system becomes obvious. Now in order to better appreciate the depth and background of this difference, it may be help-. ful to take a look at how the American systems came into being, but not in the same depth that the Japanese system was analyzed.

II. DEVELOPMENT OF THE DIALECTIC APPROACH IN THE UNITED STATES

Influence of European Philosophy

The influence of early Greek, Roman, German and English philosophy is basic but is beyond the scope of this paper. It is enough to simply state that it began when Greek civilization developed the dialectic method of reaching decisions, "first invented by Herakleitos during 523 B.C."9 Another evidence is that it was Zeno of Elea, who authored the famous paradox during 5th century B.C. and was recognized by Aristotle as its inventor.

Another major influence was English philosophy, particularly of the type embodied by John Locke. He was the inventor of the age of enlightenment and reason in England, 
France and more so in the American Constitution. Even after his death they still influenced on the life as well as thought of the West. ${ }^{10}$ The place of rationalism in Western culture is also important. The New Encyclopedia Britanica defines rationalism in the following manner:

In philosophy, a method of inquiry that regards reason as the chief source and test of knowledge and against empiricism tends to discountenance sense experience. It holds reality itself and has an inherently rational structure, there are truths, especially in logic and mathematics but also in ethics and metaphysics. In ethics rationalism relies on a 'natural light' and in theology it replaces supernatural relation with reason. 11

Puritan and Work Ethics, and Value of Success

of major importance among the several unique factors of American society the Puritan Ethic, Judeo-Christianity and the tremendous emphasis placed upon success. A good example is the concept of the self-made man exemplified by Benjamin Franklin, who was a believer in the rational way of thinking as well as being in accord with the Puritan belief. In the opening paper of his autobiography, he states that, "Now I speak of thanking God, which led me to the means I used and gave them success." It is true, God helps those that help themselves. 12 oftentimes in traditional America, it was not enough merely to enjoy a satisfactory existence in order to justify one's being, it was necessary to become a "success." Success in the American sense and value system was related directly to either financial gain or a gain in status. According to Kluckhorn, measura- 
ble as well as visible achievement and the gain of higher status and success have been of main importance and were arrived at in a uniquely American manner. Along with the value of success, other values such as freedom, equality, progress in the American sense of words needs to be kept in mind. 13 This type of success was ordinarily measured in one of two ways; by the ability of an individual to rise above his father's station in life, meaning financial position and status, or to rise above one's own initial status in life. 14 Because of the Puritan Ethics and Work Ethics in American culture, this success was regarded as not merely desirable and good, but almost as righteous itself. Richard Huber states, "Americans worship success. It was because America from early in its history, worshiped a God they were confident wanted them to be a success."15. These feelings of success and righteousness are deeply related, but are not as prevalent today. Yet it was one of the first developments of a uniquely American system. Since Americans perceived success as the way to become worthwhile human beings in the eyes of the world, this stimulated them to succeed at any cost.

The American ideal of achieving personal success by one's own means can be a starting point for someone from Japan to understand the American culture. For example, Andrew Jackson and Abraham Lincoln are regarded as having been great Presidents. The reason for their being regarded 
thus has much to do with the fact that both of them went from a log cabin to the White House. In Klapper's analysis of the ideal successful figures, both represent the category of independent spirit. His other categories are winners, heroes of special acceptability, 'splendid performers and group servants represent the ideal successful figures. 16

\section{Ecologica1 Setting}

Coupled with this tremendous desire for success was the unique ecological system of the North Continent. America, as opposed to most other rich lands, has not until very recent years experienced crowding or a shortage of resources to any degree. Each individual has been in a position to use what is regarded as an unlimited amount of resources and power for himself.

This ecological fact of life undoubtedly was a major factor in shaping the American ethos, consciousness and perceptions. There was no need to accommodate to others in America. If one disliked the type of people one was associated with, he could always "Go West", as Horace Greely suggested. There was always an escape - somewhere to go, a way to better one's position in life. Conflict would often be resolved by'simply moving on. This is because the average American had the need for personal success, but could satisfy it without competition due to the tremendous land and other resources available per capita. 
Accommodation or cooperation was, in most cases, unnecessary and certainly rarely carried the weight that it did in Japan. Therefore, cooperation until only recently, has never been necessary for survival in America and often might have hindered the possibilities of one man reaching his own success. Charles A. Reich, in his book, The Greening of America, states American people particularly, on the part of youth, are becoming more group oriented in terms of the consciousness III. ${ }^{17}$ The exception was the need of the early pioneers and settlers of the West to band together and cooperate for survival against nature and the Indians.

In America today, it is the writer's premise that a sense of isolation, privacy and (in David Reisman's term) the motion of inner-direction developed because the need to succeed now faces obstacles with the competition for space and resources and to "keep up with the Jones."18

Cooperation could be a hindrance to individual succes, so dialectic took on a new importance in American society since escape was no longer possible and competition now inevitable. In early U.S. history, to be an American meant to be, in most cases, an immigrant.

\section{Influence of Immigrants}

The immigrants who came to America were from virtually every country and society in the world, having almost nothing in common except a desire to better their own lives. 
Since the United States was a mixture of so many heterogeneous cultures and diverse backgrounds, there was bound to be difference of opinion and way of life. This lack of homogeneity made cooperation difficult since one group did not really know what the other wanted.

Verbal explanation and the presentation of various points of view was essential. This often results in the isolation of individuals and conflict between factions. Despite the great amount of potential conflicts inherent in American culture, many strikingly original and valuable ideas are able to come forth. To insure continuation of society, rules are formulated to deal with opinion differences, such as majority rule.

Some cultural mixing has occurred by now, however, some still have a notion of cultural plurality with competition, and misunderstanding occurring. At the same time, Japan is very homogenous socially, ethnically, racially and linguistically; people look alike, act alike, think alike due to centuries of similar conditioning.

It can be seen from these inputs that American communication styles were first derived from classical European traditions, but thereafter strongly modified by the particular conditions and situations of America and the American citizens, thus creating a system unique to this continent. 
III. CONTRAST OF U.S. AND JAPAN METHOD OF REACHING AGREEMENT

As a current check on the historical analysis thus far presented, interviews of American businessmen were conducted.

Among the American people being interviewed, there was a general agreement that it is one's personal convictions, contributions, achievements, and arguments and not a person's age that is of major importance in the consideration of an idea. Neither is status in the company important once the management level has been reached. Another tendency was noted by Mr. Carl Kato (Manager of World Trade and Transportation at Chamber of Commerce in Portland) who stated, "From my own experience in the United States, the manager takes direct responsibilities for decisions which he has approved". He went on to say that, "others in the company who have presented ideas and convictions also are held responsible for these. From my own experience working for a Japanese company and observing other companies while in Japan, once a decision has been reached, it is virtually impossible to pin-point any responsibility on any person".

Mr. George Nakata (Deputy Director Trade Development Port of Portland) mentioned, "In any group discussion, all members of the group, no matter what their status in the 
group, are expected to contribute their own opinions and ideas and not to be simply present." In this connection, Mr. Robert Hunt (Director of Western Wood Product Association) remarked, "People are expected to present how they feel about the decision being suggested and everyone is expected to have different opinions and should have his own strong convictions."

Generally, it was reported that Americans preferred open discussions and disagreement which was regarded as a value as well as a healthy sign if it was presented constructively. Japanese groups were far different. Group participation was not heaveily emphasized and disagreement was for the most part avoided by all parties. It has been thought to be a kind of taboo that lower echelons address their opinions freely in Japan.

As far as social code, seniority system, life-time employment and others are concerned, age and status override generally personal achievements. 


\section{CHAPTER IV - - NOTES}

$1_{\text {Dean C. Barnlund, Public and Private Self in Japan }}$ and the United States, Tokyo: Simul Press, 1975), pp. 136-137.

${ }^{2}$ Paul Edwards, The Encyclopedia of Philosophy, Volume III (New York: The MacMillan Company and the Free Press), p. 385. 1964).

${ }^{3}$ Noboru Kobayashi, Dialectic (Tokyo: Aoki Publishers,

${ }^{4}$ Dean C. Barnlund \& Franklyn S. Haiman, The Dynamics of Discussion (Boston: Houghton Mifflin Company, 1960), pp. 169-164.

${ }^{5}$ Leonard Rico, "Organizational Conflict, A Framework for Reappraisal" Industrial Management Review, Volume 6, No. 7, (Fal1 1964), pp. 67-68.

6 Fremont A. Sha1l, Jr. \& Andre L. Delbecq \& L. L. Cummings, Organizational Decision Making (New York, San Francisco, McGraw-Hill Book Company, 1970), p. 242.

7 Private Interview with Mr. George Nakata, Deputy Director Trade Development, Port of Portland, held in his office at Port of Portland.

${ }^{8}$ Edmund s. Glenn, Semantic Difficulties in International Communication, Vol. II, No. 3, 1954, p. 176.

${ }^{9}$ Hiroshi Noguschi, Theory of Catastrophe (Tokyo: Rodanhsa, 1973), pp. 35-36, and Tomio Shimizu, Ethics and Society (Tokyo: Reibunsha, 1967), p. 45.

10Ibid, Shimizu, pp. 100-102

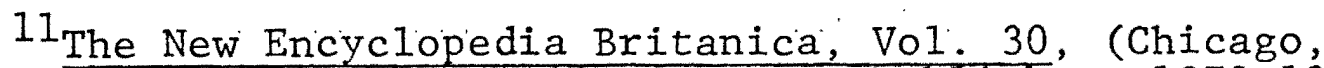
London, Toronto, Tokyo: William Benton, Publisher, 1973-1974), p. 430 .

12Leonard W. Labaree etal. The Autobiography of Benjamin Franklin, (Conn: New Haven, 1964), p. 45. 
${ }^{13}$ Clyde Kluckhorn, "Some Aspects of American National Character" in Human Factors in Military Operations, Richard H. Williams (ed) Technical Memorandum ORD-T-259. (Chevy Chase, Maryland), 1954, pp. 94-111.

14 James Michener, The Revolution in Middle Class Values. New York Times Magazine, Aug. 18, 1968, p. 87.

15 Richard M. Huber, The American Idea of Success, (McGraw-Hi11 Company, 1971), p. 107. 27-28.

160. Klapp, Heroes, Villains and Fools, (N.F. 1962), pp.

${ }^{17}$ Charles A. Reich, The Greening of America, (New York, London \& Toronto: A National General Company, 1970), pp. 417-419.

\section{${ }^{18}$ Ibid, Klapp..p. 187.}

${ }^{19}$ Series of Private Interviews with: (1) Mr. Robert Hunt, Director of Marketing Services, Western Wood Products Association, Portland, Oregon, July 25, 1975; (2) Mr. George Nakata, Deputy Director Trade Development, Port of Portland, Portland, Oregon, July 26, 1975; (3) Mr. Carl Kato, Manager, World Trade \& Transportation, Division of Portland Chamber of Commerce, July 14, 1975. These interviews were held in their offices. It should be noted that they have been heavily involved not only in international business but with transactions and negotiations with Japanese counterparts. 


\section{CHAPTER V}

\section{SUMMARY AND IMPLICATIONS}

It should be borne in mind that virtually in any human society on this planet, the view of verbal communication as a pragmatic vehicle to facilitate the operations of the society, to make decisions and achieve these decisions is paramount. ${ }^{2}$ Communication is generally looked upon as a means of welding or bringing human beings together, of formulating and carrying out decisions; as a tool or instrument to enable people to carry out functions of their societies. 4 The position of the writer is not to dispute this basic theory but to point out that differences in societies due to different type of communication that takes place in any given time in one society which might be radically different in another society because of different priorities. This means that in an intercultural setting a great deal of miscommunication may be occurring.

The Japanese system of communication as opposed to the American system is a case in point that has been under discussion in this study. Both systems accomplish what they set out to accomplish, that is, they facilitate the workings of society. However, they do so in radically different manners and achieve different specific goals. In the 
West, communication generally lays emphasis on verbal aspects which usually consist of transmission of facts, information and data for making decisions, argumentative analysis, and a search for the truth as the means of solving problems. 5 This dialectic process, at the same time, often results in isolation of individuals and conflicts between factions. Despite the great amount of potential conflict inherent in this particularly American system, many strikingly original, unique and valuable ideas are able to come forth. To insure the continuation of society, the opinion differences are reconciled by means of formulated rules, such as voting procedures.

The Japanese communication systems have developed in response to a crowded environment requiring cooperation and submerging of the individual for survival of the group. Hence, Japanese communication patterns are structured so as to preserve social harmony by promoting the idea of the community of feeling. ${ }^{6}$ Direct expression of one's views, inner-feelings, and, even more, argumentation and disagreement are looked upon as undesirable. To be brief in words or statements is still considered to be a virture and a ritual. The people in the East (including China and India and particularly Japan) simply do not communicate the same way that people in the West communicate.

The result of all this is a cohesive, cooperative society, relatively free of conflict in which decisions are 
made slowly and carried out with tremendous force.

In Japan, communication is more often used as a means to express empathy and sympathy with people rather than communicate specific or articulate ideas. This limits the amount of new ideas but they are easier to enforce when they occur due to support of the full group.

To clarify these generalizations, the following will describe the usual ritual of the U.S. - Japan interactions.

When both parties reach the negotiating table, the American side wishes to proceed quickly to the center of the discussion; they like to announce their conclusions first and follow with argumentation in the dialectic manner and justification for those conclusions, expecting the Japanese side to do the same.

However, the Japanese approach is to determine whether or not the negotiators are prepared to adjust to each other's positions and, hence, to start slowly and continually spend ample amounts of time in generalization and introductory talk, some of it striking the American counterparts as irrelevant and time consuming.

Mr. Hunt, Portland businessman associated with leading Japanese lumber industries, commented, "We find it quite frustrating in some areas to carry on for a long time. We are used to getting answers within a short period of time."7

This is partly because the initial order of business in Japan is the establishment of a personal relationship 
between the parties which will allow them to speak freely and to give and get favors. When Japanese pause in their conversations, American counterparts feel awkward and compulsively fill the gaps with brisk interventions, pushing impatiently to the problems at hand; to the "nitty gritty" as they will probably explain. As Mr. Nakata, an American businessman, said, "Americans who are used to communicating in the Western world suddenly encounter communication barriers that make them feel unnecessary frustration". 8 chagrined by the seeming lack of response to their comments and to their vigorous way of presentations, the Americans react with annoyance, failing to discern the cultural reasons behind the attitude. 9

At the same time, the Japanese are undergoing adverse reactions. The moment the Japanese confronts himself with a situation where he has to give the answer dialectically to the questions being asked by the American counterparts, the latter feels uneasy with the vacillation. The Japanese may find the American counterparts coersive for he is accustomed to the non-dialectic of affective communication in the system of hierarchy.

Search of historical records indicates that the Japanese communication behaviors of sense of discipline, benevolence, self-depreciation, vagueness of language and advatism are derived from the system of hierarchy and need for harmony, and have their roots deep in history. 
This means that they are firmly entrenched and accepted as a natural and normal behavior.

The U.S. communication style of dialectic argumentation is no less strongly determined by its cultural heritage and just as well established. There is very little evidence that either of these two groups is well aware of different communication styles and process of communication. Misunderstandings which might formally have been regarded as slight or rather unimportant, take on increasing significance in our shrinking and changing world. Unfortunately, conflicting interests are now beginning to cause problems between the United States and Japan. Since Japan is a resource poor country and, at the same time, a highly industrialized one, it must import the vast majority of the resources and raw materials needed to run its industrial and economic structure. These resources must of necessity often times come from countries which have a deep enmity towards the United States. Japan must therefore, create good relationships with both the United States and her rivals needing the energy, food and raw materials from all exporting countries including the industrial military ones. Japan also must strive to maintain a relatively independent and neutral foreign policy toward the third world as well as developing countries, lest Japan be the victim of political black mail. To do all this, Japan must sometimes act against the vital interests of the United States as seen 
by the United States government, which causes the United States to feel distrust and disappointment, failing to realize that Japan has no choice but to take steps to insure its national survival. Also Japan's industrial base, though smaller than that of the United States, is often in direct competition with the United States for available materials, thus placing an additional strain on the relationship between the two nations. This is mainly due to the competition for resources in an increasingly resource short world. ${ }^{10}$

A recent example of what has caused tension between Japanese foreign policy and U.S. foreign policy would be the warm attitude which the Japanese government has shown toward mainland China, and the conciliatory attitude of the Japanese government towards the Organization of Petroleum Exporting Countries plus the gradual warming trend in Soviet-Japanese relations.

These problems must be considered major, but need not lead to irreconcilable differences between Washington and Tokyo. Each country still needs to represent the other which gives a base for negotiation.

After having researched the difference in the manner of decision-making used by each of these two countries and the deep traditions behind these differences, it seems likely that/either the United States and Japan would be effective or comfortable using the style of the other to reach an agreement. Yet, understanding must be reached and-po- 
tential stumbling blocks and conflicts resolved. It is high time for the intercultural communication specialist to step in and act alongside the interpreters to help negotiations. Time will come sooner than later that Japan must move away from consensus because of the lengthy time factor and apply a new type of method to meet today's changing world environment and economic entity. Otherwise, the method prevelant today might not function smoothly under the condition of crisis as in the case of World War II.

In conclusion, in our attempt tó solve intercultural communication problems, particularly in the area of reaching agreement, it is important to be aware of one's own culturally and historically influenced communication patterns. When Edwin Hall outlined the theory of the way culture communicates, he suggested, "...the real job is not to understand foreign culture, but to understand our own first."11 Each must learn how he himself communicates in contrast with others, isolate the different behaviors, and understand respectfully the historical and cultural basis of each. Most important is to avoid his own way of communication as the only valid method.

Business leaders and government teams in particular must attempt to overcome the cultural bonds which have created their communication styles and arrive at some multilateral method of communication in which misunderstandings. or frictions will not have the potential to grow as they 
have today. Without a broader understanding of communication and making a good use of it, as John Condon states, "We will continue to try to improve communication merely by repeating the same thing in a loud voice."12

Separate from the thesis but a stong feeling of the writer is that if Japan overcomes. its "Amae feeling" toward the United States and begins to realistically assess Japan's position and strength and if the United States strives to achieve a greater understanding of Japan and begins to regard Japan for what it is - a major world power, then the future for the relationships between the two nations' diplomatic, business, cultural and strategic areas will be bright. These two culturally different nations and people are the most powerful in the Pacific Rim in which two thirds of the world population is living. Eugene J. Kapler, chief economist in the United States-Japan trade council remarked as follows: "Dramatic developments in the world economy since 1970 have changed the nature of the United StatesJapan relationships. The new era began when both countries found themselves confronting complex economic problems for which solutions must be sought in a global rather than bilateral setting in this multipolar world."13 
CHAPTER V -- NOTES

1

Chie Nakane, The Condition for Adaptation (Tokyo: Kodansha Pub1., 1972), pp. 137-148.

2Hiroshi Nakai, Communication Structures (Tokyo: Diamond Pub., 1974) pp. 226-235.

${ }^{3}$ Zbigiew Brzezinski, The Fragile Blossom (New York, Harper \& Row Pub., 1972), pp. 49-51.

${ }^{4}$ Isamu Kurita, Yujiro Nakamura and Kazuo Morimoto, Logos and the World (Tokyo: Shincho Pub., 1971), pp. 12-13.

5 Yoshio Abe, Dialogue with West (Tokyo: Kawase Shobo Pub., 1972)p.13.

6Masao Kunihiro, The Japan Interpreter (Tokyo: JCIE, Vo1. 8, Winter, 1973), p. 97.

${ }^{7}$ Private Interview with Mr. Robert Hunt, Director of Marketing Services, Western Wood Products Association, Portland, Oregon.

${ }^{9}$ Sen Nishiyama, Understanding-Misunderstanding (Tokyo: Simul Press, 1972), pp. 70-75 and John K. Emerson, Japanese and Americans in a New World in a New Age (New York: Japan Information Service, 1973), Pp. $11+5$ and also the writer's experience witnessing interaction between American and Japanese businessmen at Western Forestry Center on Oct. 11, 1974 at the invitation of Western Wood Products Association.

${ }^{10}$ Ibid., Emerson, p. 21.

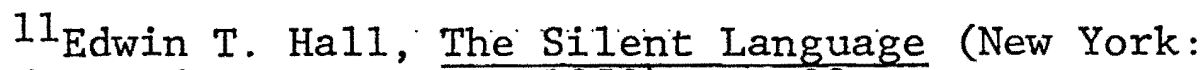
Doubleday and Company Inc. 1959), p. 39.

12 John C. Condon, An Introduction to Intercultural Communication (Indianapolis \& New York: The Bobbs-Merril1 Company, Inc. 1975), p. 3:

$13_{\text {Eugene J. Kaplan, The United States and Japan; A }}$ New Economic Relationship Washington, D.C.: U.S.-Japan Trade Council, 19.752,. p. 3. . . 


\section{APPENDIX I}

\section{CHRONOLOGICAL CHART}

Pre and Proto-Historical Eras

?-ca. 250 B.C. Jomon culture

ca. 250 B.C. -

A.D. 250 Yayoi culture

660 B.C.

Mythical date of the accession of the first Emperor, Jimmu

ca. 100 B.C.

Rice cultivation in wet fields commences.

A.D. 57 The Japanese Kingdom of $\mathrm{Nu}$ sends an envoy to the Chinese court of the Later Han Dynasty.

139

The ruler of Yamatai, Himiko, sends an envoy to the Chinese Kingdom of Wei.

Yamato Period (CA. A.D. 300-710)

ca. 300

The imperial family establishes its hegemony over Japan.

ca. 400

Writing is introduced from Korea through China.

538 (or 562)

Buddhism is introduced from Paikche in Korea through China.

562

The Japanese colony of Mimana in

Korea is conquered by Silla.

$593-622$

Prince Shotoku is regent.

604

The "Constitution of Seventeen Articles" is issued.

The Horyuji is constructed. 
645

701

Nara Period (710-784)

710

712

720

743

752

ca. 780

784

Heian Period (794-1185)

794

794

858

$939-940$

ca. 1002-1019

1016

1086

1167
The Taika Reforms are initiated.

The Taiho Code is completed.

The capital is established in Nara (Heijokyo).

The compilation of the Kojiki is completed.

The compilation of the Nihongi is completed.

Private ownership of reclaimed land is permitted.

The Great Buddha of Todaiji is dedicated.

The compilation of the Manyoshu is completed.

The capital is moved to Nagaoka.

The capital is moved to Kyoto (Heiankyo).

Seiitaishogun is appointed to subdue the Ezo.

Fujiwara Yoshifusa is appointed regent.

Taira-no-Masakado leads a rebellion.

The Tale of Genji is written.

Fujiwara Michinaga is appointed regent.

The cloister government is estab1ished.

Taira-no-Kiyomori is appointed chancellor (dajo daijin). 
1175

1180

1185
The Pure Land Sect is founded by Honen.

Minamoto-no-Yoritomo challenges the Taira family.

The Taira family falls.

Kamakura Period (1185-1333)

1192

1205

1224

1253

1274

1333

1334

1335

1336
Yoritomo is appointed shogun.

Hojo Yoshitoki becomes regent to the shogun.

The True Pure Land Sect is founded by Shinran.

The Nichiren sect is founded by Nichiren.

The first Mongol invasion occurs.

The Kamakura Bakufu collapses.

The Kemmu Restoration is estab1ished under Emperor Godaigo.

Ashikaga Takauji rebels against the imperial government.

Emperor Godaigo flees to Yoshino and establishes the Southern Court.

Ashikaga Period (1338-1573)

1338

1392

1401

$1467-1477$

1495

1506
Takauji becomes shogun.

The Southern and Northern courts are united.

The third shogun, Yoshimitsu, establishes relations with Ming China.

The Onin War

Hojo Soun captures Odawara.

The painter Sesshu dies. 
1543

1549

1568

1573

1582

1586

1587

$1588-1598$

1588

1592

1598

1600
A Portuguese ship arrives at Tanegashima.

St. Francis Xavier arrives to propagate Christianity.

Oda Nobunaga occupies Kyoto.

The last Ashikaga shogun is deposed by Nobunaga.

Nobunaga is assassinated.

Toyotomi Hideyoshi is appointed chancellor (dajo daijin).

Christianity is banned by Hideyoshi.

A land survey is conducted under Hideyoshi.

Hideyoshi confiscates arms from the peasants.

Japan invades Korea.

Hideyoshi dies.

Tokugawa Ieyasu triumphs in the Battle of Sekigahara.

Tokugawa Period (1600-1867)

1603

1635

$1637-1638$

1639

1643

1716
Ieyasu is appointed shogun.

The system of alternate attendance of daimyo in Edo is introduced.

The Shimabara Rebellion

The nation is closed to the outside world.

Buying and selling land is prohibited.

Tokugawa Yoshimune becomes the eighth shogun and initiates the Kyoho Reforms.

The ban on Western books is relaxed. 
1724

1782-1787

1787

1791

1792

1793

1801

1825

$1833-1837$

1841

1849

1853

1854

1858

1867
The playwright Chikamatsu dies.

The Temmei Famine

Matsudaira Sadanobu becomes roju (senior councilor)

Lady Washington arrived in Kushimoto, Japan.

A Russian vessel commanded by Laxman arrives in Hokkaido, asking for commercial relations.

The novelist Ihara Saikaku dies.

Motoori Norinaga dies.

An edict to drive off foreign vessels is issued.

The Tempyo Famine

Oshio Heihachiro leads an insurrection.

Roju Mizuno Tadakuni initiates the Tempo Reforms.

The woodblock artist Hokusai dies. Commodore Perry arrives.

The Treaty of Kanagawa is signed with the United States.

Ii Naosuke is appointed great councilor (tairo); a commercial treaty with the United States is concluded; the woodblock artist Hiroshige dies.

Shogun Keiki restores political power to the imperial court.

Meiji Period (1868-1912)

1868

A new government is established; Tokyo (formerly Edo) becomes the capital. 
Four major daimyo relinquish control over their han to the imperial government.

1871

The han are replaced by prefectures. the postal system is introduced; Tokugawa class distinctions are eliminated; the Iwakura mission is dispatched to the West.

1872

1873

The Tokyo-Yokohama railroad is opened; the freedom to buy and sell land is granted; compulsory elementary education is instituted.

The Gregorian Calendar is adopted (Dec. 3, 1872 of the old lunar calendar is converted to Jan. 1, 1873); universal military conscription and a new land tax are instituted.

1874

1876

- A request for the establishment of a national assembly is submitted by Itagaki and others.

The wearing of swords by former samurai is banned.

Saigo Takamori rebels.

1879

1881

1884

The Ryukyu islands become Okinawa Prefecture.

A national assembly is promised by the government.

The peerage is created; the Chichibu uprising occurs.

The cabinet system is adopted. Ito Hirobumi becomes the first Prime Minister.

Electric lighting is introduced.

1888

The Privy Council is established.

The Constitution is promulgated. 
1890

1894

$1894-1895$

1898

1902

1904-1905

1910

1912
The First Diet convenes; the Imperial Rescript on Education is issued; telephone service is introduced:

A treaty revision is agreed upon between Japan and England.

The Sino-Japanese War

The Okuma-Itagaki cabinet is formed.

The Anglo-Japanese Alliance is concluded.

The Russo-Japanese War

Korea is annexed; Kotoku Shusui and others are executed.

Emperor Meiji dies.

Taisho Period (1912-1926)

1914

1915

1918

1921

1923

1925

1926

Showa Period (1926-

1931

1932

1933
Japan enters the First World War. The Twenty-One Demands are presented to China.

The Hara Cabinet is formed.

The Washington Conference on naval arms limitations convenes.

The Great Earthquake

Universal manhood suffrage is enacted; radio broadcasting commences.

Emperor Taisho dies:

The Manchurian Incident

Prime Minister Inukai is assassinated; party government ends.

Japan withdraws from the League of Nations. 
Minobe Tatsukichi's Organ Theory is condemned.

Prominent leaders are assassinated by radical militarists; the AntiComminteran Pact with Germany is concluded.

War with China breaks out.

1940

Japanese troops move into French Indochina; a tripartite alliance with Germany and Italy is concluded.

1941

Japan attacks Pearl Harbor and the Pacific War begins.

1942

The Battle of Midway (June)

1944

The tide of war shifts. Saipan falls; Prime Minister Tojo resigns; U.S. bombers carry out massive air raids on Japanese cities.

U.S. troops land in the Philippines and Okinawa; atomic bombs are dropped on Hiroshima and Nagasaki;

Russia enters the war; Japan surrenders; Allied occupation under General MacArthur begins.

A new constitution is promulgated.

General Tojo and others are executed.

1951

1952

The peace treaty is signed in San Francisco.

The Allied occupation ends .

A United States-Japanese Mutual Security Agreement is signed; television broadcasting begins.

Japan is admitted to the United Nations.

A new United States-Japan Mutual Security Agreement is concluded. quish control of Okinawa by 1972 . 
1974

President Ford visited Japan (the first American President ever to visit Japan).

1975

The Emperor Hirohito visited the United States.

Based on Japan, Historical Survey, by Mikiki Hane, (New York: Charles Scribner!s Sons, 1972, Appendix.A. 
APPENDIX II. GRAMMAR (LEVELS OF FORMALITY)

\section{Forma1 Language}

Formality differences in Japanese may be divided roughly into three levels, the informal, the semi-formal and the formal. In very general terms, the informal level is characterized by wide usage of informal endings; in the semiformal level, the semi-formal endings of the predicate; i.e. the verb, the verbal adjective or the copula, is in the semiformal form, although internally within the sentence, these verbs, etc. occur in the informal form; the formal level is characterized by the use of different vocabulary, i.e. more formal equivalents of verbs, nouns, etc. occurring in the other two levels, but these new verbs may occur with informal or semi-formal endings. In short, the semi-formal incorporates the endings of informal speech and the formal level incorporates informal and semi-formal endings.

In addition to the usual difference of close friendship which exists in other languages also, there is in Japanese a distinction of "insider" and "outsider." The Japanese is consciously or subconsciously aware whether the person whom he is addressing or the person of whom he is speaking belongs to his circle and is thus an "insider" or is outside his own circle and is thus an "outsider." One's immediate inside circle is usually one's family. A second 
inside circle might be one's office circle or perhaps one's classmates in the case of a school child. Within one's circle one would use the informal or semi-formal level of speech; these two levels distinguish the relative closeness of the individuals concerned rather than the "insider" "outsider" concept. Formal language, however, makes a clear distinction between the speaker and the other person, the "insider" and the "outsider" to such an extent that the mention of the subject is often unnecssary. The humble and honorific forms of the formal language distinguish this factor. This is because the selection of verbs is such that the "outsider" is always placed in a higher position than the speaker. In short, whenever the reference in such a case is to "you," the honorific is used and whenever the reference is to "me," the humble is used. In such a coversation, when the topic is more neutral such as in the case of an object or a third party not directly connected with either the speaker of address, a so-called neutral verb may occur. Examples of such verbs are gozaimasu or orimasu. Let us take the example of a secretary who is referring to her employer. If she were speaking with a member of another firm, she would refer to her employer using the humble form, because the individual she is addressing is the "outsider." If, however, she were speaking to her employer's wife, she would use the honorific form, as she herself is now the "outsider." 
All Japanese verbs have an honorific form of the formal language, the form used in referring to a second or third person. Most verbs form this in the regular way, that is by prefixing an honorific o to the root of the verb and adding ni narimasu. Only the verb narimasu is conjugated. See the following examples of such verbs.

$\begin{array}{ll}\text { tsukur-u } & \text { otsukuri ni narimasu } \\ \text { yom-u } & \text { oyomi ni narimasu } \\ \text { kak-u } & \text { okaki ni narimasu } \\ \text { mat-su } & \text { omachi ni narimasu } \\ \text { ka(w) -u } & \text { okai ni narimasu } \\ \text { kake-ru } & \text { okake ni narimasu } \\ \text { kari-ru } & \text { okari ni narimasu }\end{array}$

These same verbs, ones with a regular honorific form, also have a regular humble form, the form used of the first person. This is formed by prefixing the honorific o to the root of the verb and adding suru. This form means "I will do it", "I will do it for you." The following are examples of the regular humble honorific.

$\begin{array}{ll}\text { tsukur-u } & \text { otsukuri shimasu } \\ \text { yom-u } & \text { oyomi shimasu } \\ \text { kak-u } & \text { okaki shimasu } \\ \text { mat-su } & \text { omachi shimasu } \\ \text { ka (w) -u } & \text { okai shimasu } \\ \text { kake-ru } & \text { okake shimasu }\end{array}$

(Note that there is also an irregular humble honorific, haishaku shimasu.) 
Some of the most commonly occurring verbs, such as those of eating, drinking, coming, going, have irregular humble and/or honorific forms in formal language. They change to entirely different verbs. For example, the verb $\mathbf{i k u}$, "to go" is mairu in the formal humble and irrassharu, oide ni naru or omie ni naru in the formal honorific. For a list of these verbs which occur in this text, see the chart on page 485 . The chart on page 487 shows the conjugation of one of these verbs, illustrating with the verb "go."

In the same way that there are two imperative forms in the informal level, there are two imperatives in the formal level. One form is the gerund of the verb alone or the gerund plus kudasai: itte or itte kudasai. In the formal leve1, this is irasshatte or irasshatte kudasai(mase). (Note that kudasai may become kudasaimase.) This form has the meaning "Won't you please do -..- (for me)?" The second imperative is a direct command. In the informal level, it is ike for the verb "go." In the formal level, it is irasshai. These have the meanings "Go!" The root of the verb plus nasai is a direct command on the semi-formal level; an honorific o before this is a direct command which is a little politer. In practice, one does not usually give a command to someone in a higher position but rather a suggestion that he do such and such. Example: Oyomi ni nattara ikaga desu ka or "How would it be if you read it?" 
EXAMPLES:

yome

yomi nasai

oyomi nasai

Read it!

yonde kudasai

oyomi kudasi

Please read

it (for me)!

ike

iki nasai

oiki nasai

Go!

itte kudasai

irasshai

irasshatte kudasai Please go

(for me)!

Based on Basic Japanese for College Students by Tamako Niwa and Mayako Matsuda, (Seattle and London: University of Washington Press, 1970) PP 490-491 


\section{APPENDIX III}

LIST OF PARENTS ANSWERS TO: "What are the first things you taught your child to do other than walk or talk? Examples: forms of etiquette, sitting positions, etc."*

Manners and courtesies: (how to perform, as well as occasions on which to do so)

Properly to sit, stand, bow, and eat

Express gratitude for something the child is given

Traditional hand position when receiving anything

Greet a visitor

When to visit another's house

Bow before and after meals

Properly to give a good answer; how to answer "yes" and "no"

Speak quietly

Eat everything that is served

Appearance and cleanliness:

How to wash face and limbs

Wash hands before meals, face in the morning, and hands when he returns home.

* Based on a sample of a hundred questionaires. 
Keep one's limbs clean

Wipe feet when one returns home

Brush teeth

Blow his nose cleanly always

Comb his hair

Discipline and training:

Toilet habits

Parents' bidding

Go on errands

Help mother

Come home at mealtime

Study hard

Tell everything that happens in school each day

Return things to their places

Place things neatly

Treat various articles carefully

Arrange zori (sandals) in the doorway when returning home

Cautious in traffic

Go to sleep alone

Play alone with toys and picture books

Go to bed and rise early

Worship gods

Put one's hands together in worship skills

A-baba (patting on the mouth)

Choncho (clapping of hands) 
0-tsumu-tenten (patting of head with one's hands)

Kaiguri (Simple game: elbows flexed, hands in front of chest, turn them as if pulling in a rope.)

Ro11 over on stomach

Craw1

Build blocks

Clap one's hands

Beckoning

Wave hand Bai-Bai (Japanese spelling and pronunciation for the English "bye-bye")

Names of things - flowers, foods, animals

Names and faces of family members

Words: (in Japanese) - thank you; mother and father;

please

Words to say:

Preceding and following a meal

When entering and leaving the house

In greeting and bidding farewell to someone

The meaning of "come here" (in Japanese)

The words, banzai and gutto-bai ("good bye")

Distinguish trains, streetcars, automobiles, and

other vehicles

Distinguish colors

Distinguish sounds, one from another

Songs and music

Dance to music 


\section{Count}

The child's own name and address

Picture books, paper folding, drawing, reading, writing

Simple characters and figures as the child asks How to hold and use a pen, brush, spoon

How a bowl should be held in the hands

Wear Zori

Independence - to stand when he falls, to arrange his toys neatly by himself

Behavior toward others:

Friendliness

Select good friends

Offer toys and sweets to others

Play harmoniously with others

Distinguish another's property

LIST OF PARENTS' ANSWERS TO: "What are the things you taught your child not to do? Examples: wet his clothing, go barefooted outside the house, etc."

Cautions: Do not

Touch anything hot or dangerous

Play in a dangerous place

Go far away alone

Go into the street 
Go without a hat in the summer

Play with cutlery

Play with fire

Go out without giving notice

Cleanliness and health measures: Do not

Soil one's limbs

Enter the house with soiled feet

Let your nose run

Put your fingers in your mouth

Put a toy in the mouth

Sit down and play on the ground

Pick up soiled things in the street

Eat filth

Go into the rain without an umbrella

Drink water

Soil one's clothes when urinating

Wet the bed

Urinate at the gate

Relations to others: Do not

Quarre1

Envy (want anything a child has or is holding)

Make another child cry

Say spiteful things to another

Ill treat another child

Hit or beat anyone with hand or stick 
Have a vicious thought

Trouble others

Trouble others when walking

Do mischief to a stranger

Take another's property

Throw stones

Discipline and manners: Do not

Oppose the teachings of your parents

Answer or talk back

Touch books or anything that is set neatly one on top

of another

Scribble on the walls

Break anything

Tear the paper on the shoji (sliding inner doors)

Throw or tear anything

Touch paints or india ink

Play in a disorderly manner

Get into mischief

Be naughty

Eat sweets without permission

Act peevish in front of a shop to get something

Tell a lie

Play without clothes

Suck your mother's breast

Waste money

Fail to study hard 
Lie down after eating

Tumble down the veranda

Get your head off the pillow

Eat at another's house

Confuse the outside with the inside of the house

Mentioned most frequently on a sample of fifty forms were: (beginning with the first, given in order of frequency):

TO DO: Toilet habits, polite sitting position, eat properly, manners, wash hands before meals, use chopsticks, say arigato ("thank you"), words to say preceding and following a meal, return things to their places.

NOT TO DO: Play outside without footgear, soil clothes with urine, quarrel, let food fall from the table, envy (want things others have), throw stones.

Based on "Aspect of Child Care in Japanese" in Japanese Character and Culture edited by Betty B. Lanhan. The Board of Regents of Universities \& State College of Arizona, Library of Congress, 1962. 
ADMINISTRATIVE FORM EXEMPLIFYING THE "ASSIGNMENT SYSTEM" RECOMMENDED IN 1964

Pre-Decision Consultation Post-Decision Disposition

Drafter Chief of the Live- Document No. No. stock Management

Section

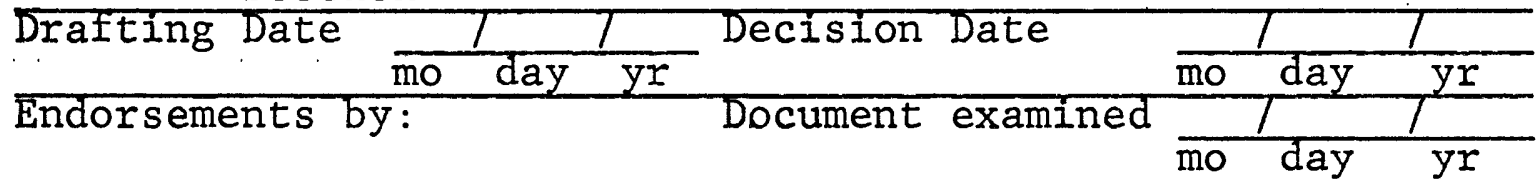

Chief, Sanitation

Section

Document revised

Chief, Natural Feeds Decision executed Section

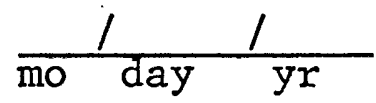

Chief, Artificial Feeds Other matters Section
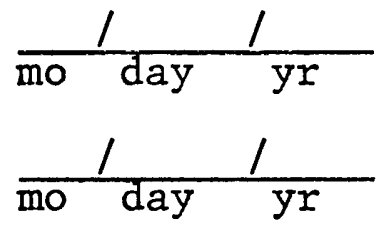

Chief, Breed Improvement Section

Chief, Economics Section

Chief, Livestock Administration Section

Counselor

Chief, Agricultural Document Filer

Economics Bureau in charge (name)

Ministerial Chief Secretary

Parliamentary Vice-

Minister File No. No.

I certify that the following decision has been made: (text of policy decided upon is appended).

(name)

Ministry of Agriculture and Forestry

Based upon "Decision-Making" in Political Development in Modern Japan by Kioaki Tsuji, Princeton University Press, New Jersey, 1968. 


\section{APPENDIX V}

SAMPLE OF A RINGISHO

Date of Final Decision

Entry made in Files

Referrer's seal

Documents Filer's seal

Bureau seal

Section seal

RE: The Establishment of Government Measures for Financial Assistance in the Expansion of the Livestock Industry.

Minister

Parliamentary Vice-

Minister

Career Vice-Minister

Ministerial Chief

Secretary

Chief of the Agricultural Economics Bureau

Counselor

Chief, General Affairs

Section

Chief of the Livestock

Chief, Finance Section

Chief, Budget Section

Chief, Local Affairs Section

Bureau

Counselor

Chief, Livestock Adminis-

tration Section

Chief, Economics

Section

Chief, Breed Improvement

Section

Chief, Artificial Feeds

Section

Chief, Natural Feeds

Section

Chief, Sanitation Section

Chief, Livestock Management

Section

Drafter 
APPENDIX VI

MODEL OF RINGISEI COMMUNICATIONS SYSTEM

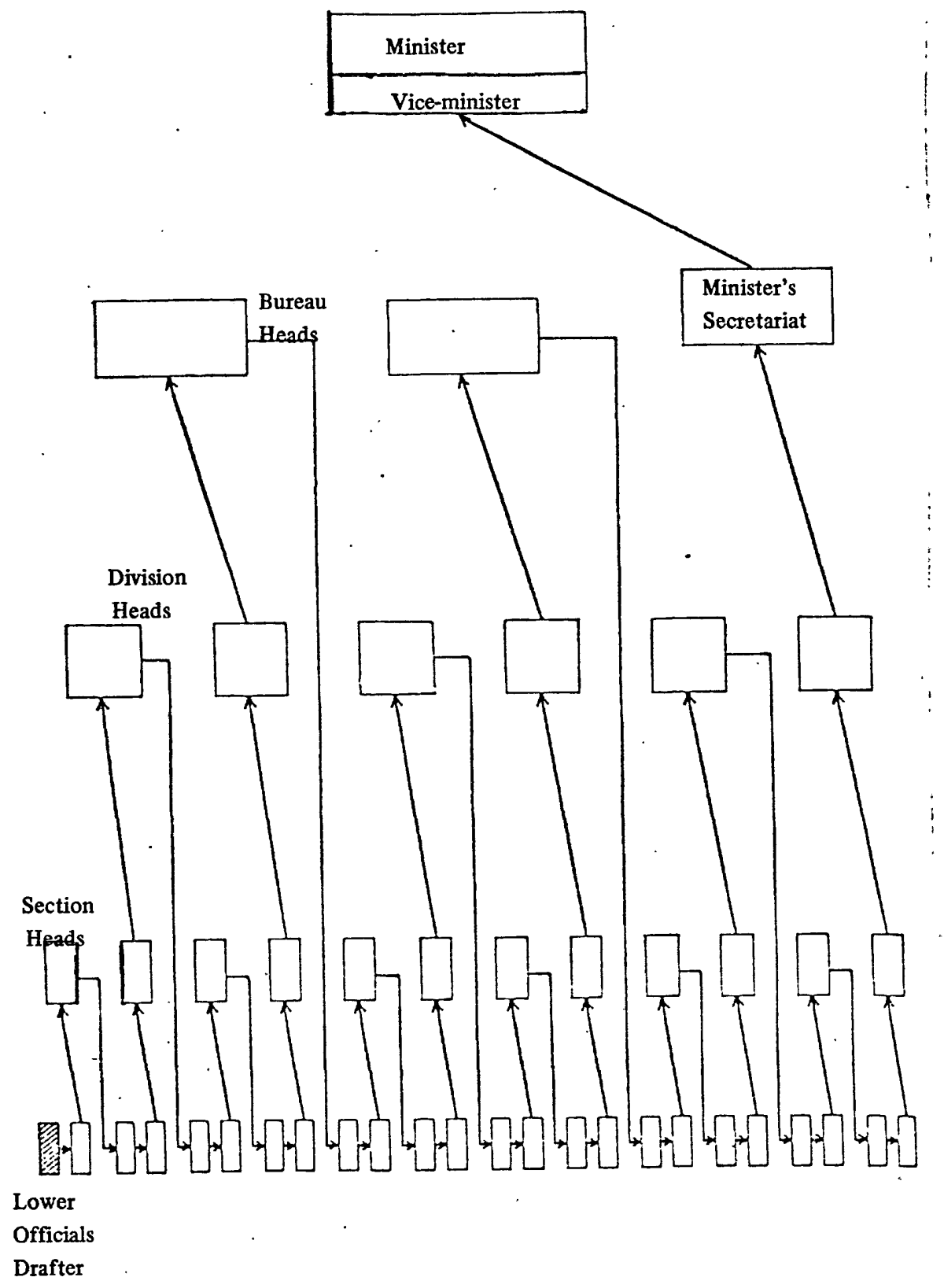




\section{A SELECTED BIBLIOGRAPHY}

Abe, Yoshio. Dialogue with West, Tokyo: Kawase Publishers, 1972

Anai, Shunzo. An Introduction of East and West, Japanese, Tokyo: Rikugei Publishers, 1971.

Araki, Hiroshi. Japanese Behavioral Patterns, Tokyo: Kodan Publishers, 1973.

Barna, LaRay M. "Stumbling Blocks in Interpersonal Intercultural Communication" Intercultural Communication: A Reader, Edited by Larry A. Samovar and Richard E. Porter, Belmont, California: Wadsworth Publishing Co., Inc., 1972 .

Balazs, Etienne. Chinese Civilization and Bureaucracy, Haven and London: Yale University Press, 1964.

Barnlund, Dean C. and Haiman Franklyn S. The Dynamics of Discussion, Boston: Houghton Mifflin Company, 1960.

. Public and Private Self in Japan and the United States, Tokyo: Simul Press, 1975.

Benedict, Ruth. The Chrysanthemum and the Sword, Boston: Houghton. Mifflin Company, 1946.

Brzezinski, Zbigew. The Fragile Blossom, New York: Harper \& Row Publishers, 1972.

Collins, Barry E., and Guetzkow. A Social Psychology of Group Process for Decision-Making, N.Y.: Hohn \& Wiley \& Sons, INO, 1964.

Condon, John C., and Yousef Fathi. An Introduction to Intercultural Communication, Indianapolis and $\mathrm{New}$ York: The Bobbs-Merrill Company, Inc., 1975.

Curtis, Gerals L. Columbia Journal, World Business, Vol VI., No. 1 (Jan. -Feb. 1973).

Dilworth, David A., and Hurst, Cameron G. Fukuzawa Yukichi's an Outline of a Theory of Civilization, Tokyo: Sophia University, 1970. 
Doi, Takeo. "The Japanese Patterns of Communication and the Concept of Amae", The Quarterly Journal of Speech, Vol. 59, No. 2, 1973.

Dore, R.D. City Life in Japan - A Study of a Tokyo Word, Berkeley, California: University of California Press, 1958.

Dozono, Sho G. Private Interview conducted at Portland State University, September 4, 1975.

Drucker, Peter. Man, Ideas and Politics, New York: Harper $\&$ Row Publishers, 1970.

Edwards, Paul. The Encyclopedia of Philosophy, Vol III, New York: The MacMillan Company and the Free Press.

Egami, Namio, Ueyama, Shunpei, Matsuda, Yoshiro and Ishida, Eichiro. Energy, Vo1. 4 (Tokyo: Oct. 1967).

Emmerson, John K. Japanese and Americans in a New World in a New Age, New York: Japan Information Service, 1973.

Glenn, Edmund S. Semantic Difficulties in International Communication, ETC., VoI. II, No. 3, 1954.

Grilli, Elise. "Okakura Kakuzo, A Biographical Sketch", The Book of Tea, Rutland, Vermont and Tokyo: Charles E. Tuttle Company, 1956.

Ha11, Edwin T. The Silent Language, New York: Doubleday and Company, Inc., 1959.

Ha11, Whitney John. Japanese History, University of Michigan Publications, 1966.

- and Beardsley, Richard $K$. Twelve Doors in Japan, New York: McGraw-Hill Book Company, 1965. Hane, Mikiko. Japan, Historical Survey, New York: Charles

Harada, Fujio. Private Interview held in Portland, Oregon. August 28, 1975.

Haylook, John. "My Impressions of Japan", Japan as Others See Her, Tokyo: Genshobo Company, Inc., 1972.

Hearn, I. An Attempt at Interpretation, Tokyo: Kenkyusha Publishers, 1975. 
Hibbett, Howard and Itasaka Gen. Modern Japanese Reader, Cambridge, Mass.: Harvard University Press, 1968.

Huber, Richard M. The American Idea of Success, McGraw-Hill Company, 1971 .

Hunt, Robert. Private Interview conducted at Western Wood Products Association, Portland, Oregon, July 25, 1975.

Ienage, Saburo. New Japanese History, Tokyo: Sanseido Publishers, 1967.

Inoue, Mitsusada. Introduction to Japanese History, Tokyo: Kokusai Bunka Shinkokai, 1968.

Ishida, Eichiro. Pursuing Human Beings, Tokyo: Kadakawa Publishers, 1968.

Ishida, Koji. The Spiritual Climate of Japan, Tokyo: Iwanami Publishers, 1974.

Ishiguro, Shigeru. Private Interview held at the Bank of Tokyo, Portland, Oregon on August 13, 1975.

Itasaka, Gen. Nihongo Yokocho, Tokyo: Shiaundo Publișhers, 1974

Johnson, Richard T. and Ouchi, William G. "Made in America", U.S./Japan Outlook Vol. 4, San Francisco: Japan Trade Center, 1975.

Kamatsu, Isao. The Japanese People, Tokyo: Kokusai Bunka Shinkokai, 1962 .

Kaplan, Eugine J. The United States and Japan, A New Economic Relationship, Washington, D.C.: U.S.-Japan Trade Council, 1975.

Kato, Hideyuki. "Why Don't We Talk?", Language Life, Vol II, Tokyo: 1961.

Keene, Donald, Baryand, Theodore De and Tsunoda, Ryusuke, Sources of Japanese Tradition, New York and London: Columbia University Press, 1958.

Kidder, Edward. Early Buddhist Japan, New York: Praeger Publishers, 1917.

Kitamura, Hiroshi. Psychological Dimensions of U.S.Japanese Relations, Cambridge, Mass.: Harvard University Press, 1971. 
Klapp, 0. Heroes, Villains and Fools, N.F., 1962.

Kluckhorn, Clyde. "Some Aspects of American National

Character". Human Factors in Military Operations,

Richard H Williams (ed) Technical Memorandum

ORD-T-259, Operations Research Office, Chevy Chase, Maryland, 1954.

Kobayashi, Koji. "Recognition of Management and Technology", Management Japan, Vo1. 6, No. 2 (Autumn, 1972).

Kobayashi, Noboru. Dialectic, Tokyo: Aoki Publishers, 1964.

Kunihiro, Masao. "Indigenous Barriers to Communication", The Japan Interpreter, Tokyo: JCIE., Vol. 8, (Winter, 1973).

Kurita, Isamu, Nakamura, Yujiro and Morimoto, Kazuo. Logos and the World, Tokyo: Shincho Publishers, 1971.

Labaree, Leonard W. The Autobiography of Benjamin Franklin, New Haven, Conn., 1964.

Legge, James. Menccius III A, 4; Chinese Classics 2, pp. 249-250.

Lewin, B. Die. Beitraege Zum Interpersonalen Bezug in Japanischen, Otto Harrassowitz: Wiebaden, 1969.

The Mainichi Daily Newspaper. Tokyo: February 20, 1974.

Michener, James. The Revolution in Middle Class Values, New York: New York Times Magazine, August 18, 1968.

Minami, Hiroshi. Japanese Psychology, Tokyo: Iwanami Publishers, 1960.

Ministry of Foreign Affairs Japan. Japan in Transition, Tokyo: Ministry of Foreign Affairs, 1975.

Miyamoto, Tadao. Language and Contemplation, Tokyo: Heibon Publishers, 1974.

Morsbach, Helmut. "Aspects of Non-verbal Communication in Japan". Nervous and Mental Disease, The Williams and Wilkins Company, 1973.

Nakai, Hiroshi. The Structure of Communication, Tokyo: Diamond Publishers, 1974. 
Nakamura, Hajime. A. History of the Development of Japanese Thought, Tokyo: Kokusai Bunka Shinkokai, 1969.

- Way of Thinking of Eastern Peoples, Honolulu, Hawaii: East West Center Press, 1964.

Nakane, Chie, Conditions for Adaptation, Tokyo: Kodan Publishers, 1972 .

- Japanese Society, Berkeley, and L.A.: University of California Pres, 1970.

Nakata, George. Private Interview conducted at Port of Portland, Oregon on July 26, 1975.

New York Times. New York: August 3, 1972.

Ninomiya, Yasuaki. Private Interview held at Western Grain Company, Portland, Oregon on July 28, 1975

Nishiyama, Sen. Understanding Misunderstanding, Tokyo: Simul Press, 1972.

Noguchi, Hiroshi. Theory of Catastrophe, Tokyo: Reibunsha Company, Inc., 1967.

Norman, Hervert. Japan's Emergence as a Modern State, Political and Economic Problems of the Meiji Period, New York: Institute of Pacific Relations, 19401

Passin, Herber. The United States and Japan, Englewood Califfs, N.J.: Prentice Hall, Inc., I966.

Reich, Charles A. The Greening of America, New York, London and Toronto: A National General Company, 1970.

Reischauer, Edwin 0. Japan, The Story of Nation, New York: Alfred A. Knopf Publishers, 1970.

. Japan's World Role in the 1970's, Speech deIivered at Lewis and Clark College, Portland, Oregon on May 9, 1973. 1964. A New Look at Modern History, Tokyo: Genshobo,

- The United States and Japan, Cambridge, Mass.: Harvard University Press, 1968.

Reisman, David. Abundance for What?, N.Y.: Doubleday Company, Inc., 1964. 
Rico, Leonard. "Organizational Conflict, A Framework for Reappraisal", Industrial Management Review, Vol. 6, No. 7 (Fal1, 1964).

Runkle, Scott F. An Introduction to Japanese History, Tokyo: International Society for Educational Information Press, Inc., 1974.

Samovar, Larry A. and Porter, Richard E. Intercultural Communication: A Reader, Belmont, California: Wadsworth Publishing Company, 1972.

Sanson, George. A History of Japan to 1334, Stanford University: Stanford University Press, 1958.

Seward, Jack. The Japanese, New York: William Morrow \& Company, 1972 .

Scheuer, Steward H. Japanese, Chinese and English, Discussion, Tokyo: Nihon Hoso Kyokai, English Program, October $31,1972$.

Sha11, Fremont A., Delbecae, Andre L. and Cumings, LL. Organizational Decision-Making, New York: McGraw Hill Book Company, 1970.

Sugi, Mastaka. "The Concept of Ninjo", Paternalism in the Japanese Economy, Anthropology Studies of OyabunKobun Patterns, Minneapolis: University of Minnesota Press, 1963.

Shimizu, Tomio. Ethics and Society, Tokyo: Reibunsha Co., Inc., 1967.

Takamiya, Susumu. Backgrounds, Characteristics and Recent Trends in Japanese Management, London: The British Institute of Management, 1970.

Taki, Komo. Yoshida Shoin Vo1. 1, Tokyo: Iwanami Publishers, 1958.

Trewartha, Glenn T. Japan A Geography, Madison and Milwaukee, Wisconsin: University of Wisconsin Press, 1965.

Van Zandt, Howard E. "How to Negotiate in Japan", Harvard Business Review, (November - December, 1970).

Weekly Compilation of Presidential Documents, Monday, January 10, Vo1. 8, No. 2, 1972.

Young, Frederic G. Oregon Historical Quarterly, Vo1. 23, 1922 . 